\title{
RELAÇÃO QUANTIDADE/INTENSIDADE DE POTÁSSIO EM SOLOS DO TRÓPICO SEMI-ÁRIDO BRASILEIRO.
}

\author{
LÜCIA HELENA GARÓFALO CHAVES
}

Orientador: TOSHIAKI KINJO

Dissertação apresentada à Escola Superior de Agricultura "Luiz de Queiroz", da Universidade de São Paulo, para obtenção do título de Mestre em Agronomia. Área de concentração: Solos $\theta$ Nutrição de Plantas.

PIRACICABA

Estado de São Paulo - Brasil

Agosto - 1983 


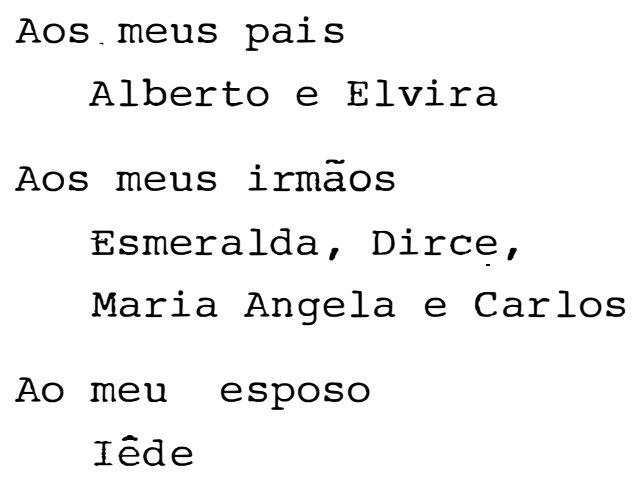

Dedico . 
Ao Prof.Dr. Toshiaki Kinjo, do Depar tamento de Solos, Geologia e Fertili zantes da Escola Superior de Agricul tura "Luiz de Queiroz", Mestre e Ami go, pela orientação segura e constan te na elaboração deste trabalho. 


\section{AGRADECIMENTOS}

Ao Departamento de Solos e Engenharia Rural do Centro de Ciên cias Agrárias, UFPB.

Ao Departamento de Solos, Geologia e Fertilizantes da Escola Superior de Agricultura "Luiz de Queiroz".

Ao Professor José Luiz Ioriatti Demattê, do Departamento de Solos, Geologia e' Fertilizantes da Escola Superior de Agri cultura "Luiz de Queiroz".

Aos Professores Décio Barbin e Antonio Francisco Iemma do Departamento de Matemática e Estatística da Escola Superior de Agricultura "Luiz de Queiroz".

Ao Engenheiro agrônomo Tarcísio Ewerton Rodrigues.

Aos técnicos de laboratōrio, Mário Benedito Lodovico e Maria Elisabete H.B. Guimarães.

Às bibliotecárias Neide Bombeiro Filet, Maria Elizabeth Ferreira e Sônia Corrêa da Rocha e ao funcionário Luiz Carlos Veríssimo, da Biblioteca Central da Escola Superior de Agricultura "Luiz de Queiroz".

A Coordenação do Aperfeiçoamento de Pessoal de Nível Superior e Programa de Integração de Capacitação de Docentes: (CAPES/PICD) . 
RESUMO $\ldots \ldots \ldots \ldots \ldots \ldots \ldots \ldots \ldots \ldots \ldots \ldots \ldots \ldots \ldots \ldots \ldots \ldots$

SUMMARY $\ldots \ldots \ldots \ldots \ldots \ldots \ldots \ldots \ldots \ldots \ldots \ldots \ldots \ldots \ldots \ldots$

1. INTRODUÇÃO $\ldots \ldots \ldots \ldots \ldots \ldots \ldots \ldots \ldots \ldots \ldots \ldots \ldots$

2. REVISÃo DE LITERATURA $\ldots \ldots \ldots \ldots \ldots \ldots \ldots \ldots \ldots$

2.1. Formas de potássio no solo ............ 5

2.2. Potássio e minerais de argila em solos da região semi-árida do Nordeste $. . . \ldots \ldots . .9$

2.3. Adsorção de potássio ............... 13

2.4. Relação Quantidade /Intensidade de potássio no solo ................. 17

3. MATERIAL E METODOS $\ldots \ldots \ldots \ldots \ldots \ldots \ldots \ldots \ldots . \ldots \ldots$

3.1 . Solos $\ldots \ldots \ldots \ldots \ldots \ldots \ldots \ldots \ldots \ldots \ldots$. 27

3.2. Adsorção de potássio..$\ldots \ldots \ldots \ldots \ldots \ldots .28$

3.3. Relação Quantidade/Intensidade de potás sio no solo $\ldots \ldots \ldots \ldots \ldots \ldots \ldots \ldots \ldots \ldots$

4. RESUltados E DisCUSSÃO $\ldots \ldots \ldots \ldots \ldots \ldots \ldots \ldots$

4.1. Adsorção de potássio ............... 36

4.2. Relação Quantidade/Intensidade de potás sio no solo $\ldots \ldots \ldots \ldots \ldots \ldots \ldots \ldots \ldots \ldots$. 51 
Página

5. CONCLUSÕES

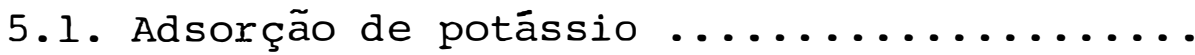

5.2. Relação Quantidade/Intensidade de potás sio no solo $\ldots \ldots \ldots \ldots \ldots \ldots \ldots \ldots \ldots \ldots$

6. LITERATURA CITADA $\ldots \ldots \ldots \ldots \ldots \ldots \ldots \ldots$ 
1 - Características físicas e composição mineralógica da fração argila dos solos .........

2 - Características químicas dos solos .........

3 - Concentração de potássio nas soluções de trạ tamento e equilíbrio; variação do potássio trocável $(\Delta \mathrm{K})$; concentração de cálcio, magnésio e sódio dessorvidos; quantidade total de potássio trocável no Vertissol (horizon -

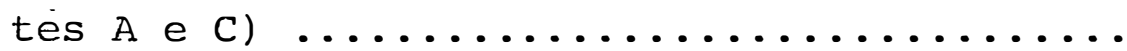

4 - Concentração de potássio nas soluções de trą tamento e equilíbrio; variação do potássio trocável $(\Delta \mathrm{K})$; concentração de cálcio, magnésio e sódio dessorvidos; quantidade total de potássio trocável no Planossol Solódico (horizontes A e B) $\ldots \ldots \ldots \ldots \ldots \ldots \ldots \ldots$ 
5 - Concentração de potássio nas soluções de trạ tamento e equilíbrio; variação do potássio trocável $(\Delta K)$; concentração de cálcio, mag' nésio e sódio dessorvidos; quantidade total de potássio trocável no Bruno Não Cálcico (horizontes A e B) $\ldots \ldots \ldots \ldots \ldots \ldots \ldots \ldots$

6 - Concentração de potássio nas soluções de trạ tamento e equilíbrio; variação do potássio trocável $(\Delta \mathrm{K})$; concentração de cálcio, magnésio e sódio dessorvidos; quantidade total de potássio trocável no Solonetz Solodizado (horizontes A e B) $\ldots \ldots \ldots \ldots \ldots \ldots \ldots \ldots$

7 - Concentração de potássio nas soluções de trą tamento e equilíbrio; variação do potássio trocável $(\Delta K)$; concentração de cálcio, magnésio e sódio dessorvidos; quantidade total de potássio trocável no Bruno Não Cálcico-vér

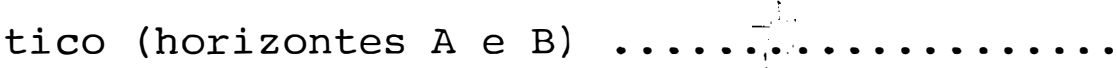


8 - Concentração de potássio nas soluções de trą tamento e equilíbrio; concentração de cálcio e magnésio na solução de equilíbrio; varia - ção do potássio trocável $(\Delta K)$ e quociente de atividade de potássio (QAK) do Vertissol (horizontes A e C) $\ldots \ldots \ldots \ldots \ldots \ldots \ldots \ldots$

9 - Concentração de potássio nas soluções de trạ tamento e equilíbrio; concentração de cálcio e magnésio na solução de equilíbrio; variação do potássio trocável $(\Delta K)$ e quociente de atividade de potássio (QAK) do Planossol Solódico (horizontes A e B) $\ldots . . \ldots \ldots \ldots \ldots$

10 - Concentração de potássio nas soluções de trą tamento e equilíbrio; concentração de cálcio e magnésio na solução de equilíbrio; variação do potássio trocável $(\Delta K)$ e quociente de atividade de potássio ( $Q A K$ ) do Bruno Não Cálcico (horizontes A e B) $\ldots \ldots \ldots \ldots \ldots \ldots$ 
11 - Concentração de potássio nas soluções de trą tamento e equilíbrio; concentração de cálcio e magnésio na solução de equilíbrio; variação do potássio trocável $(\Delta K)$ e quociente de atividade de potássio (QAK) do Solonetz

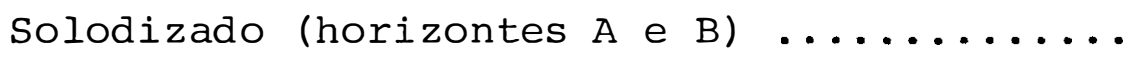

12 - Concentração de potássio nas soluções de trą tamento e equilíbrio; concentração de cálcio e magnésio na solução de equilíbrio; variação do potássio trocável $(\Delta K)$ e quociente de atividade de potássio (QAK) do Bruno Não Cálcico-vértico (horizontes A e B) .........

13 - Potássio sujeito a equilíbrio com a solução; potássio planar e preferencial atual e posições preferenciais não ocupadas por potássio, obtidós a partir das curvas Q/I de potássio.

14 - Saturação em potássio e parâmetros Q/I ....

15 - Relação entre parâmetros Q/I e algumas pro-

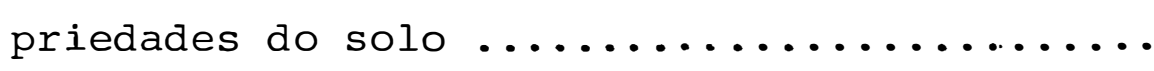


LISTA DE FIGURAS

Página

1 - Representação esquemática da curva Q/I ......

2 - Variação do potássio adsorvido em função da concentração do elemento na solução de equilíbrio do Vertissol (V); Planossol Solódico (PL); Bruno Não Cálcico (NC); Solonetz Solodizado (SS) e Bruno Não Cálcico-vértico (NCv) .......

3 - Relações entre a concentração de potássio na solução de equilíbrio e a quantidade total de potássio trocável do Vertissol (V); Planossol Solódico (PL); Bruno Não Cálcico (NC); Solonetz Solodizado (SS) e Bruno Não Cálcico-vértico ( $\mathrm{NCv}) \quad \ldots \ldots \ldots \ldots \ldots \ldots \ldots \ldots \ldots \ldots \ldots \ldots \ldots \ldots \ldots \ldots$

4 - Variação da concentração do potássio na solução de equilíbrio em função da porcentagem de saturação em potássio no Vertissol (V); Pla nossol Solódico (PL); Bruno Não Cálcico (NC); Solonetz Solodizado (SS) e Bruno Não Cálci co-vértico $(\mathrm{NCv}) \ldots \ldots \ldots \ldots \ldots \ldots \ldots \ldots \ldots$ 
5 - Curvas características da equação de Gapon para Vertissol (V); Planossol Solódico (PL) e Bruno Não Cálcico (NC) $\ldots . \ldots \ldots \ldots \ldots \ldots \ldots$

6 - Curvas representativas da relação Q/I do Ver tissol (V); Planossol Solódico (PL); Bruno Não Cálcico (NC); Solonetz Solodizado (SS) e Bruno Não Cálcico-vértico (NCv) ............. 
RELAÇÃO QUANTIDADE/INTENSIDADE DE POTÁSSIO EM SOLOS DO TRÓPICO SEMI-ÅRIDO BRASILEIRO.

Candidata: LUCIA HELENA GAROFALO CHAVES Orientador: Prof.Dr. Toshiaki Kinjo

RESUMO

Neste trabalho, procurou-se estudar, através de isotermas de adsorção de potássio e da relação Quantida de/Intensidade (Q/I), a relação entre a concentração de potássio da solução do solo e o potássio trocável, e a influẹn cia de algumas propriedades do solo nessa relação.

As amostras de terra utilizadas foram coletadas dos horizontes A e C do Vertissol e dos horizontes A e B dos solos Bruno Não Cálcico, Bruno Não Cálcico-vértico, Planossol Solódico e Solonetz Solodizado, localizados no Estado da Paraíba.

No estudo de adsorção de potássio, as amostras de $3,0 \mathrm{~g}$ de TFSA foram tratadas com soluções de potássio de concentração variando de 0,0 a 9,687 mmol/1. A solução de equilíbrio foi analisada para se determinar as quantí 
dades de potássio adsorvido e de cálcio, magnésio e sódio dessorvidos.

Para a determinação das relações Quantida de/Intensidade dos solos, foram analisados o potássio, cálcio è magnésio das soluções de equilíbrio das amostras de 0,$3 ; 0,8 ; 1,5$ e $3,0 \mathrm{~g}$ de TFSA, tratadas com soluções contendo 2 mmol/l de cálcio e quantidades de potássio variando de 0,0 a 4,357 mmol/l. Através das curvas representativas das relações $Q / I$, determinou-se os parâmetros quociente de atividade de potássio em equilíbrio (QAKe), atividade de equilíbrio de potássio (Ke) e poder tampão de potássio (PTK).

Nas condições do experimento, verificou- se que a adsorção de potássio aumenta com a elevação de sua con centração nas soluções de tratamento e que os solos que ad- . sorvem mais potássio são os que apresentam valores mais elevados de СТC. O sódio do complexo sortivo dos solos influen cia de maneira direta e proporcional a adsorção preferencial de potássio. O maior e o menor valor de PTK foram apresentados pelo Vertissol e Solonetz Solodizado, respectivamente. O parâmetro que melhor se relaciona com_a concentração de potássio na solução de equilíbrio é a porcentagem de saturação em potássio. 
Com base na relação $Q / I$, concluiu-se que os solos que apresentam potássio trocável adsorvido na posição planar, são os que mantêm maior concentração do elemento na solução. Os parâmetros QAKe e Ke correlacionam-se de manei ra significativa com a porcentagem de saturação em potássio e com a relação $\mathrm{K}^{+}$trocāvel/( $\left.\mathrm{Ca}^{2+}+\mathrm{Mg}^{2+}\right)$ trocáveis. O PTK dos solos está diretamente relacionado à CTC dos mesmos. O horizonte A de todos os solos, com exceção do Vertissol,apre senta baixos valores de PTK e mantem altos níveis de Ke. 


\section{QUANTITY/INTENSITY RELATION OF POTASSIUM IN SOILS OF BRAZILIAN TROPICAL SEMI-ARID REGION.}

Candidate: LUCIA HELENA GAROFALO CHAVES

Adviser: Prof.Dr. Toshiaki Kinjo

SUMMARY

Potassium adsorption isotherms and quantity/ lintensity (Q/I) curves were determined in order to study potassium concentration of the soil solution in relation to the exchangeable potassium and some soil properties affecting such relation.

Soil samples were collected from Vertisol, Planosol Solódico, Bruno Não Cálcico, Bruno Não Cálcico-vér tico, and Solonetz Solodizado located in the state of Parai ba. The potassium adsorption isotherms were obtained by equilibrating $3.0 \mathrm{~g}$ of soil with solutions containing potas sium, the concentration of which varied from 0.0 to 9.687 mmol/l. The equilibrium solution was analyzed to determine the amount of potassium adsorbed and the amount of calcium, magnesium and sodium desorbed. For the Q/I curves, soil sam- 
ples weighting from 0.3 to $3.0 \mathrm{~g}$, were equilibrated with solutions containing $2 \mathrm{mmol} / \mathrm{l}$ of calcium and amounts of potassium varying from 0.0 to $4.357 \mathrm{mmol} / \mathrm{l}$; the equilibrium solution was then analyzed for potassium, calcium and magnesium. Equilibrium activity ratio $\left(A R_{e}^{K}\right)$, equilibrium potassium acti vity (Ke) and potential buffer capacity $\left(\mathrm{PBC}^{\mathrm{K}}\right)$ were obtained from the $Q / I$ curves.

The potassium adsorption, under the experimen tal conditions, increased with its concentration in the equi librium solution, and the soils with hịgher cation exchange capacities tended to adsorb more potassium. Exchangeable sodium affected in the diret and proportional way the preferen cial adsorption of potassium. The highest and lowest. $\mathrm{PBC}^{\mathrm{K}}$ values were observed in the Vertisol and in the Solonetz Solodizado, repectively. The parameter which showed the best correlation with the potassium concentration of the equilibrium solution was the base saturation percentage. Based on the Q/I relation, it was concluded that soils having the exchangeable potassium adsorbed in the planar position maintain the best concentration of the element in the solution. The parameter $\mathrm{AR}_{\mathrm{e}}^{\mathrm{K}}$ and Ke were significantly correlated with the potassium satura tion percentage and the exchangeable $\mathrm{K}^{+} /\left(\mathrm{Ca}^{2+}+\mathrm{Mg}^{2+}\right)$ ratio. The $\mathrm{PBC}^{\mathrm{K}}$ of the soils was directly related to their cation 
exchange capacity. The A horizon of all soils except the Ver tisol had low values of $\mathrm{PBC}^{\mathrm{K}}$ and maintained higher levels of Ke. 
1. INTRODUÇÃO

o estudo da disponibilidade de potássio para as plantas envolve o conhecimento de vários fatores como a con centração de potássio na solução, o teor do elemento na forma trocável, a capacidade do solo em manter uma dadà concentração na solução quando as plantas retiram o potássio desta, e as ca racterísticas do solo que afetam a difusão do elemento até a superfície das raízes. Estes fatores, de modo geral, podem ser estudados em várias etapas.

A respeito da concentração de potássio na solução do solo, pode se dizer que é função, principalmente, da quantidade do elemento adsorvido, da força de retenção exercida pelo material coloidal e da presença-de outros cátions no complexo sortivo. Sua avaliação pode ser feita através do estudo da adsorção ou da relação Quantidade/Intensidade. 
Pela adsorção de potássio a concentração do elemento em solução é determinada apenas em relação ao seu teor trocável, não sendo considerada a influência que outros cátions exercem sobre a dinâmica do elemento no complexo sor tivo.

Porém, considerando que no șolo os potenciais do potássio, cálcio e magnésio estão relacionados, foi pro posto por BECKETT (1964b) um método de avaliação do potás sio o qual relaciona o quociente da atividade deste elemento com o cálcio mais o magnésio, denominada de intensidade (I), com a quantidade ou reserva do potássio no solo (Q). Com este método é possivel avaliar, através de um gráfico,a con centração do potássio na solução do solo em relação ao cál cio e magnésio também presentes na solução e a resistência que oferece o solo de variar o parâmetro intensidade.

O conhecimento do gráfico da relação Q/I de ưn solo, na prática, é de grande importância porque, atra vés dele, pode-se prever a variação que será observada na concentração de potássio na solução, quando uma determinada quantidade deste elemento é adicionada ou retirada do solo.

No presente trabalho, a adsorção de potássio e a relação Quantidade/Intensidade foram determinadas em solos 
da região semi-árida do Estado da Paraíba. Estes são pouco intemperizados e pouco lixiviados, contendo na fração argila minerais expansíveis e tendo teores elevados de bases trocáveis no complexo sortivo. O critério de escolha de tais solos baseou-se nos diferentes teores de sódio e na composição mineralógica variável que apresentam, possibilitando, assim, observar a interferência,destes fatorés na concentração de potássio da solução.

Outro motivo foi a falta de conhecimento até o presente, a respeito da capacidade - destes solos em man ter níveis adequados de potássio na solução ..., apesar de possuirem teores do elemento na forma trocável, variando en tre médio e alto.

Finalmente, por acreditär numa futura exploração agrícola intensiva na região de ocorrência de tais sô los, possibilitada pelo emprego de determinadas práticas co mo irrigação, drenagem, adubação, etc., achou-se necessário uma avaliação preliminar da situação atual do potássio dos solos, a qual foi realizada em duas etapas tendo os seguintes objetivos:

1. Estudar a adsorção do potássio relacionan do-a às propriedades dos solos. 
2. Avaliar, através da relação Quantidade/In tensidade, a concentração de potássio na solução de equilíbrio de diferentes solos, correlacionando-a com suas propriedades. 
2. REVISÃO DE LITERATURA

\subsection{Formas de potássio no solo}

O potássio total do solo pode ser dividido em vārias formas, tendo como finalidade a facilidade de seu estudo. Esta divisão, conforme CRISOSTOMO e CASTRO (1970) é pụ ramente arbitrária devido à não existência de um limite bem definido entre uma forma e outra. LOPES (1982) concorda com - fato de ser extremamente difícil avaliar o comportamento das várias formas do potássio do solo devido a elas: estarem em equilíbrio dinâmico, porém, acredita ser possível isolar, num dado espaço de tempo, a contribuição delas para o teor de potássio total do solo.

Diversas classificações têm sido propostas pa ra caracterizar as formas de potássio no solo. Assim, com ba se em sua utilização pelas plantas, o potássio pode ser clas 
sificado da seguinte maneira: a) potássio facilmente utilizável ou prontamente disponível, que inclui a forma trocável e em solução; b) potássio moderadamente utilizável ou lentą mente disponivel, onde se incluem as formas fixadas e as da biotita; c) potássio dificilmente utilizável ou não disponível, como o dos feldspatos e da muscovita (ATTOE e TROUG , 1945; Tisdale e Nelson, 1975 citados por LOPES, 1982).

Sob o aspecto do equilíbrio do potássio no sô 10, RITCHEY (1979) propôs as formas: a) potássio que ocorre como um componente estrutural de minerais, tais como micas e feldspatos potássicos, e que se torna disponível apenas quando estes minerạis são decompostos; b) potássio temporaria mente "fixado" entre lâminas de argilas expansivas tais como ilita e montmorilonita; c) potássio facilmente trocável por um sal neutro, não tamponado, como acetato de amônio e uma pequena quantidade de potássio presente na solução do so 10

De maneira geral, a classificação mais utilizada, a respeito das formas de potássio no solo, é a seguinte: a) potássio estrutural, que corresponde ao encontrado nos minerais primários como muscovita, biotita e feldspatos, e na mica secundária ou ilita; b) potássio-solução, que se 
encontra na solução do solo, podendo ser absorvido pelas plantas e/ou lixiviado; c) potássio trocável, o qual pode estar adsorvido em três diferentes posições de troca: planar, "p" (su perfícies planas externas dos minerais de argila; externa, "e" (bordas das partículas); interna, "i" (interior das partícu las, entre as camadas com minerais de argila (MIELNICZUK, 1980).

Conforme MIELNICZUK (1980), essas três formas de potássio correspondem, respectivamente, de 90 a 98 \%; de 0,1 a $0,2 \%$ e de 1 a 2 do potássio total do solo. Como se pode observar, a fração de potássio-solução é muito pequena; sua concentração na solução do solo varia entre 0,0025 e 2,5 mmol/1, sendo considerado baixo os níveis entre 0,025 e 0,10 mmol/l, e adequado, acima de 0,5 mmol/l (FASSBENDER, 1980).Na maioria dos solos brasileiros o teor de potássio na solução é geralmente considerado báixo e insuficiente para manter con tínuo o desenvolvimento vegetal.

Para que o equilíbrio dinâmico entre as formas de potássio ocorra è necessário que haja liberação, tan to do elemento estrutural, como do trocável para a solução do solo. A ocorrência disto, porém, está na dependência não só da concentração do potássio na solução do solo, mas também da reserva do elemento ligada à fase sólida do solo, sua capacidade de repor os íons na solução do mesmo e dá influên 
cia exercida pela presença de outros cátions, como por exemplo, cálcio e magnésio na solução do solo (KHASAWNEH, 1971).

A liberação do $\mathrm{K}$ estrutural depende da quantí dade e tipo de minerais primários facilmente intemperizados, portádores de potássio, existentes no solo. O equilíbrio man tido por esta forma do elemento com a solução do solo não é considerada de grande importância para os solos brasileiros uma vez que a maioria deles, por serem altamente intemperiza dos(predominando os minerais de argila, caulinita e gibsita), pos suem minerais potássicos resistentes à intemperização. A validade desta afirmação, porēm, é posta em dúvida por RAIJ (1981) devido ’a falta de pesquisas conclusivas sobre o assunto.

De maneira geral, pode-se dizer que os mine rais primários constituem a fonte de potássio a médio e longo prazo, e_que o potássio trocável e o da solução, a reserva imediata do elemento no solo (Grimme, 1976, citado por MIELNICZUK, 1980).

Segundo CATANI e JACINTHO(1974), o teor de Ktrocável nos solos é considerado alto quando for maior que 0,30 meq/100 g; médio entre 0,30 e 0,10 meq/100 g e baixo, quando inferior a $0,10 \mathrm{meq} / 100 \mathrm{~g}$. 
Um estudo para quantificar as formas de potás sio em 81 solos de várias regiões do Brasil, feito por CASTRO et alii (1972), demonstrou que 67, 60 e 49 o dos solos possuem teores de $\mathrm{k}$-total $<20 \mathrm{meq} / 100 \mathrm{~g}$, K-não trocável $<0,35 \mathrm{meq} / 100 \mathrm{~g}$ e $\mathrm{K}$-trocável <.0,15 meq/100 g, respectiva mente, e que aproximadamente $50 \%$ dos solos analisados possuem teores de $\mathrm{K}$-trocável entrẹ médio $(0,16-0,30 \mathrm{meq} / 100 \mathrm{~g}) \mathrm{a}$ alto ( 0,30 meq/100 g). Uma ressalva feita por MIELNICzUK (1977), a respeito destes dados, alerta para o fato de que todos os teores de potássio variam com a adubação e utilização do solo, podendo levar, assim, a conclusões errôneaș a respeito da situação atual do potássio nos solos brasileiros.

2.2. Potássio e minerais de argila em solos da região se$\underline{\text { mi-árida do Nordeste }}$

A fração argila dos solos é comumente composta de uma mistura de minerais primários e secundários.A iden tificação de tais minerais é de extrema importância, uma vez que, através dela, pode-se inferir muitas das propriedades físico-químicas dos solos.

Os solos da região semi-árida, devido à natureza de seus materiais de origem, sua inadequada drenagem e à baixa precipitação a que estão sujeitos, ainda contêm, de 
maneira geral, minerais primários de fácil intemperização , constituindo fontes de potássio para as plantas. Na fração areia destes solos podem ocorrer em diferentes proporções , feldspatos potássicos e biotita intemperizada. O solo solonetz Solodizado constitui exceção à regra, apresenta: baixa porcentagem de minerais primários ou não os apresenta (BRASIL, 1972) •

Contudo, MOREIRA (1979), caracterizando pedons de Solonetz Solodizado do Sertão Central e do Médio Jaguaribe do Estado do Ceará, encontrou feldspatos potássicos em razoáveis proporções, tanto na fração areia muito fina, como no silte e argila. Observou também; que na fração argila dos pedons estudados predominam os minerais de argilạ do tipo 2:1 sobre a caulinita.

Resultado semelhante foi encontrado por OLI VEIRA (1981), através de estudo mineralógico de um perfil de Solonetz Solodizado da planície do Rio Paramirim (BA) - O autor constatou a presença de minerais de argila do tipo 2:1 e que estes se formam devido a alterações de feldspatos, sobre tudo plagioclásio, e de micas (muscovita e biotita). 
Estudos de caracterização mineralógica de Gru mossolos (Vertissóis), localizados na bacia sedimentar do Recôncavo Baiano e região do Médio São Francisco, foram realizados por DIAS (1971) e HAROWITZ e MAKITIE (1963), respectivamente. Estes observaram que nos solos das duas regiões pre domina o mineral montmorilonita, e que em oito perfis do Recôncavo Baiano ocorre a seguinte distribuição de minerais: 40,4 a 59,4 $\%$ de montmorilonita; 11,7 a $23,2 \div$ de mica; 0,0 a $21,7 \div$ de caulinita e 2,7 a $11,1 \div$ de material amorfo. Nos solos do Médio São Francisco ocorre também beidelita em teores elevados.

Conforme CAMARGO e BENNEMA (1966), um delinea mento esquemático dos Vertissóis do Brasil, mostrou a predominância da montmorilonita na fração argila de tais solos . Tambēm em Grumossolos (Vertissōis) de várias regiões do mundo, como o Sudoeste do Kansas,o Texas,a região Leste do Arizona e a Jamaica, -apesar de possuirem materiais de origem dị ferentes, a fração argila destes solos é dominada por montmo rilonita e menores quantidades de mica (ilita) e caulinita, possuindo,às vezes, vermiculita (JARVIS et alii, 1959; JOHNSON et alii, 1962; NELSON et alii, 1960 e AHMAD e JONES, 1969). 
As argilas de alta atividade, como é o caso da montmorilonita, são também encontradas em solos Bruno Não Cálcico, Bruno Não Cálcico-vértico e Planossol Solódico (BRA SIL, 1972). Além desse mineral, em perfis deste último, localizados na Zona do Agreste de Pernambuco, foi constatada a ocorrência, na fração argila, de mica e caulinita (FERREIRA, 1978) .

Conforme CASTRO et alii (1972), o teor de potássio total dos solos, está ligado ao grau de evolução destes e ao regime pluviométrico. Os autores observaram, pela análise de oitenta e um solos brasileiros, que os maiores va lores de potássio total correspondem àqueles que ocorrem em zona de baixa pluviosidade, como por exemplo, solos Bruno Não Cálcico, fase caatinga, dos Estados do Ceará e Paraỉba , com 36,4 e 80,0 meq/100 g, respectivamente, e Vertissol, fase caatinga, do Estado do Rio Grande do Norte, com 68,0 meq/100 g. Os teores de potássio trocável encontrados para estes solos foram 0,12;0,21 e 0,61 meq/100 g, classificados os dois prí meiros como teor médio e o terceiro como alto (CATANI e JACINT HO, 1974) .

Quanto ao suprimento de potássio dos solos aci ma mencionados, foram encontrados teores acima de 0,35 meq/ 
$100 \mathrm{~g}$, o que demonstra não haver problemas de deficiência do elemento naqueles solos (CASTRO et alii, 1972).

Segundo MARANHÃO et alii (1974), o Vertissol de Cachoeirinha e o solo Bruno Não Cálcico de Jataúbà, ambos na região do Agreste de Pernambuco, apresentam alta capacidade de suprimento de macronutrientes, especialmente de potássio e cálcio. Os seus teores de potássio trocável correspondem a 0,40 e $0,30 \mathrm{meq} / 100 \mathrm{~g}$, sendo considerados como alto e médio, respectivamente (LEITE, 1973).

Em Planossol Solódico da mesma região, foi en contrado por FERREIRA (1978), teor de potássio trocável em torno de 0,50 meq/100 g, o qual não difere muito dos teores encontrados nos Planossois Solódicos da zona do Agreste e Cạ atinga Litorânea do estado da Paraíba (BRASIL, 1972).

\subsection{Adsorção de potássio}

O fenômeno de adsorção de cátions, atualmente também chamado de troca catiônica, foi descoberto no século passado e após alguns anos, descrito em detalhes por Way em 1850 (SCHUFFELEN, 1972). Consiste, basicamente, na neutralização, pelos cátions, das cargas elétricas negativas existentes na superfície da matéria orgânica, minerais de argila e óxidos hidratados de ferro e aluminio. 
As cargas negativas originam-se das substituições isomórficas que ocorrem quando da formação dos cristais, ou da dissociação dos îons $\mathrm{H}^{+}$dos grupamentos silanol, aluminol, carboxílico, fenólico, etc., que fazem parte da estrutura das partículas coloidais do solo. No primeiro caso, são chamadas de cargas permanentes, sendo constan tes em sua magnitude e nas demais, denominadas de cargas variáveis ou dependentes do pH. Estas variam tanto em sua natú reza quanto em magnitude, aumentando conforme o pH do meio se eleva (SCHUFFELEN, 1972 e RAIJ, 1981).

Dentre os minerais de argila têm-se os dos grupos de smectita, hidromica_e vermiculita, que apresentam cargas permanentes, e aqueles do grupo dos minerais de argila do tipo $1: 1$, que possuem cargas variáveis. Embora a montmorilonita (smectita) seja capaz de adsorver íons potássio, apenas ilita (hidromica) e vermiculita apresentam forças especí ficas de retenção dos mesmos.

Segundo RAIJ (1981), tambēm a matéria orgânica, os óxidos de Fe e Al e os materiais amorfos apresentam cargas negativas variāveis. 
Desde a descoberta do fenômeno de adsorção, uma das maiores preocupações dos pesquisadores é determinar relações (ou isotermas) entre a quantidade de ions adsorvidos e sua concentração na solução. As primeiras, inclusive empíri cas, para adsorção de cátions, foram as de Freundlich e Lang muir; correspondendo a funções logarítmica e hiperbólica, res pectivamente. Em seguida, surgiram as mais modernas, como por exemplo a de Vanselow, Gapon-Bolt, Kerr e Donnan, que se dife renciam das anteriores principalmente por relacionarem diferentes íons (SCHUFFELEN, 1972).

A equação de Gapon, como a de outros autores, baseia-se na lei de ação das massas e considera, num sistema de troca de íons divalentes por monovalentes, a equação de equilíbrio da seguinte forma:

$$
\frac{\gamma^{+}}{\gamma^{++}}=k_{G} \frac{c^{+}}{\sqrt{c^{++}}},
$$

onde: $\gamma$ = ions adsorvidos, meo $/ 100 \mathrm{~g}$

c = ions na solução de equilíbrio, mol/l

$\mathrm{K}_{\mathrm{G}}=$ constante de Gapon, $(\mathrm{mmol} / 1)^{1 / 2}$.

A constante de Gapon $\left(\mathrm{K}_{\mathrm{G}}\right)$, segundo FASSBENDER (1980), é uma derivação empírica para descrever o processo de troca catiônica, porém, Schofield (1947), Errickson (1952) e 
Bolt (1967), citados por SCHUFFELEN (1972), acreditam que ela tenha fundamento físico, sendo função da densidade de carga das superfícies dos colóides.

Conforme BECKETT e NAFADY (1967), a constante de Gapon é representada pelas inclinações das isotermas de troca catiônica que ocorrem nos solos, por exemplo entre $\mathrm{K}$-Ca, sendo estas descritas, adequadamente, pela equação de Gapon.

O potássio trocável, fator quantidade do eḷemento no solo, como já foi comentado, pode estar adsorvido em três posições distintas nos minerais de argila, sendo que na planar, não é específica a adsorção de potássio; na preferen cial externa existe alguma seletividade quanto à adsorção do elemento, crescendo ainda mais na preferencial interna. Desta maneira, tem-se uma maior concentração de potássio na solução do solo. (fator intensidade) se esta for mantida pelo elemento adsorvido na posição planar, ou ainda, quando as posições seletivas de adsorção de potássio forem totalmente saturadas e um número suficiente de posições planares for ocupado pelo elemento (QUEMENER,1979).

No processo de adsorção ou troca catiônica, deve ser considerada a natureza do outro cátion que estará competindo na troca. Segundo Singh e Talibudeen (1968), citados 
por TALIBUDEEN (1972), em solos com pH acima de 5,5 ○ ion cálcio domina o complexo de troca. Já em solos com pH inferior ao citado, o complexo de troca é dominado, de maneira crescente, pelo ion aluminio e é este íon, quando presente,juntamente cam o íon cálcio num solo saturado e rico em ilita, o que provavelmente controla a troca iônica do potássio.

Segundo. RAIJ (1981) o teor do potássio em solução depende dos teores de cálcio e magnésio, e.quanto maior forem estes, menor os teores em solução daquele, para um mesmo teor de potássio trocável do solo.

\subsection{Relação Quantidade_. Intensidade de potássio no solo}

No estudo da disponibilidade de nutrientes para as plantas é preciso avaliar a quantidade dos nutrientes na solução e suas reservas na fase sólida do so 1o, uma vez que é esta a responsável pela manutenção do equilíbrio entre as äuas fases.

Schoefield (1947) citado por MIRANDA e IGUE (1972), foi quem introduziu o conceito de potencial químico como parâmetro relacionado à disponibilidade de nutrientes 
para as plantas e no caso do elemento potássio, potencial po tássico. Porém, BECKETT (1964a) pesquisando sobre as formas de medida do potencial potássico, chegou à conclusão de que a disponibilidade de potássio no solo, ou, sua troca pelo elemento cálcio, estavam na dependência não só do potencial potáśsico, mas também do cálcico. Desta maneira, introduziu o conceito de quociente de atividade do potássio, QAK = aK/ / $\sqrt{\mathrm{aCa}}$, que é uma medida do potencial químico do potássio em relação ao do cálcio presente na solução do mesmo solo. Este quociente é também conhecido como fator Intensidade (I) e é proporcional à diferença de potenciais químicos do potássio e do cálcio de troca.

Como os elementos magnésio e cálcio possuem propriedades de troca semelhantes, vários pesquisadores têm os tratado como única espécie, admitindo o quociente de atí vidade do potássio, QAK, como aK/ $\sqrt{\mathrm{aCa}+\mathrm{aMg}}$ (BECKETT, $1964 a)$.

Diferentes solos podem apresentar o mesmo va lor de QAK, porém, com capacidades diferentes em mantê-lo en quanto o potássio é removido pelas raízes das plantas ou é lixiviado. Assim, para se descrever o estado do potássio num solo, é preciso especificar o valor atual do QAK e também a 
forma da relação Quantidade/Intensidade, sendo quantidade (Q) o valor do potássio trocável do solo (BECKETT, 1964b).

Segundo BECKETT e NAFADY (1967), o termo quantidade (Q) é difícil de ser definido e avaliado, por isso,quan do eśtudado em relação ao QAK, deve ser medido em termos de $\Delta \cdot K$. Este representa a quantidade de potásssio adsorvido ou dessorvido pelo solo quando em equilỉbrio com soluções de diferentes QAK. Em outras palavras, $\Delta K$ é estimado como a diferença entre as concentrações de potássio em uma solução antes e depois da adição desta no solo. Um gráfico de $\Delta K$ versus QAK tem a mesma forma de outro que relacionasse valores de $Q$ com os de QAK.

A Figura 1 apresenta o gráfico característico . da relação Q/I. Ele mostra de que maneira a quantidade de potássio trocável $(\Delta K)$ varia em função do QAK da solução do sọ 10 .

No estudo de vários solos de Oxford, feito por BECKETT (1964a), foi constatado que os gráficos correspondentes à relaçao Q/I de cada um deles, tiveram a mesma tendência, isto é, uma parte superior linear e uma inferior curva assintótica em relação ao eixo $Q$. 


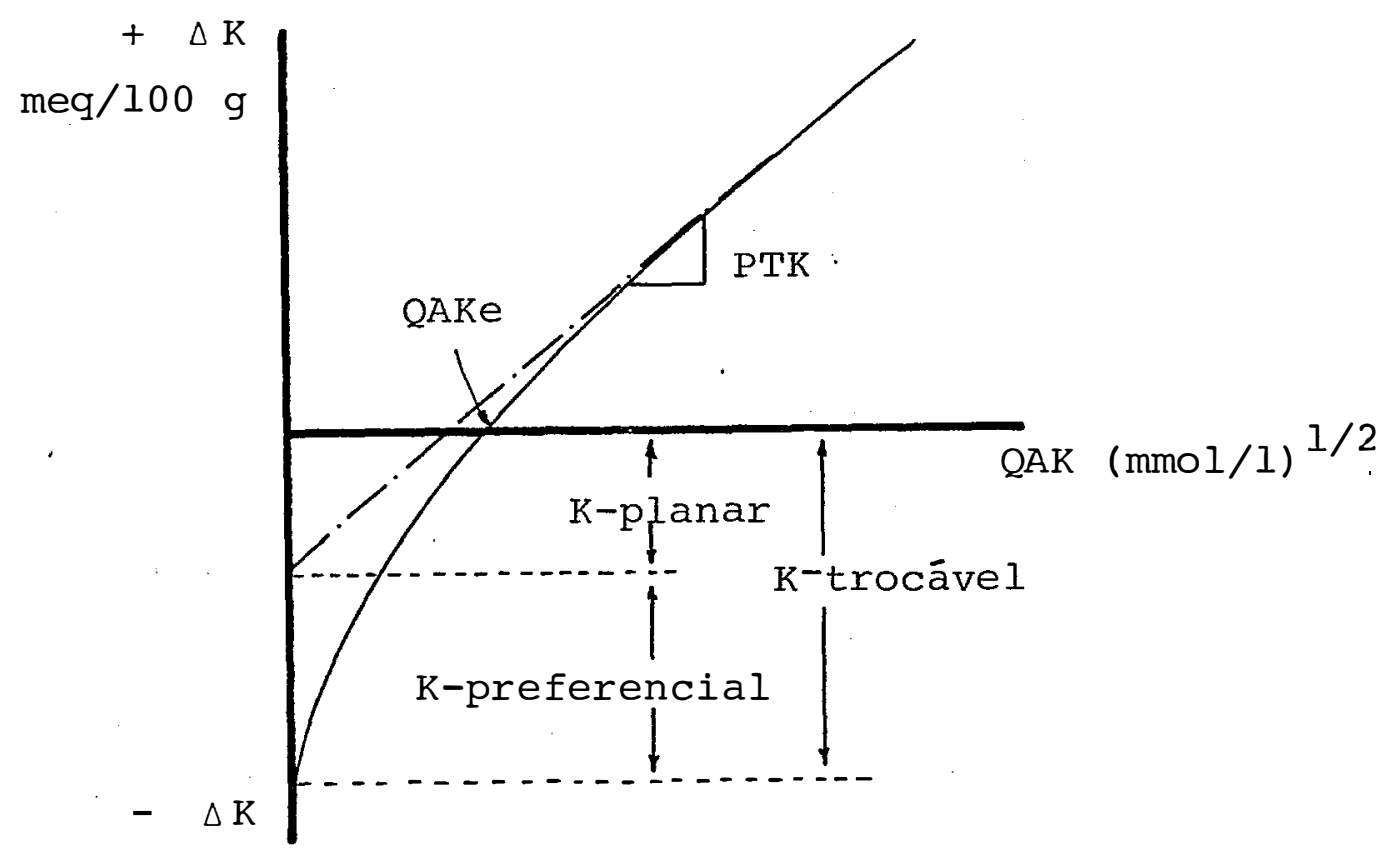

Figura 1 - Representação esquemática da curva Q/I). Fonte: (MIELNICZUK, 1980).

A inclinação $\Delta Q / \Delta I$ representa $\circ$ poder tampão de potássio do solo (PTK) tendo maiores valores, en concentrações mais baixas de potássio trocável do solo, devido ao aumento do coeficiente de seletividade, ou seja, da maior retenção do potássio em relação ao cálcio mais magnésio (MIELNICZUK, 1980).

A parte inferior do gráfico representa a quan tidade total de potássio trocável presente no solo; a dife rença entre os valor'es de $\Delta K$ correspondentes à extrapolação da região reta do gráfico e a extremidade da sua região cur- 
va, corresponde ao potássio preferencial ("e" e "i") ou, a : capacidade de sítios específicos para adsorção de potássio;o potássio planar, desta maneira, è a diferença entre potássio trocável total e potássio preferencial (BECKETT e NAFADY, 1967).

Os parâmetros obtidos através da curva $Q / I$ va riam com as características físico-químicas e mineralógicas dos solos. Assim, conforme a composição do complexo sortivo ou o tipo de argila predominante nestes, o potássio pode ser menos ou mais facilmente liberado para a solução.

Em estudos feitos por BOLARIM et alii (1980) sobre o comportamento das argilas caulinita, montmorilonita e ilita, em relação ao potássio, os maiores teores ; do ele mento nas posições planar e preferencial foram encontrados na ilita: As razões disto são a maior afinidade desta argila pelo potāssio e a existência, neste mineral, de posições específicas para o potássio preferencial (BOLT et alii,1963). Essa mesma argila foi a que apresentou o mais elevado $\operatorname{PTK}\left(235,7 \mathrm{meq} / 100 \mathrm{~g} /(\mathrm{mol} / \mathrm{l})^{1 / 2}\right)$ e consequentemente, o menor valor de QAKe $\left(0,00722(\mathrm{~mol} / \mathrm{l})^{1 / 2}\right.$.

Os solos, quando adubados ou corrigidos pela calagem, têm seus complexos sortivos modificados, o que contribui para a variação dos parâmetros de Q/I. 
Quanto à adubação potássica, foi constatado que ela aumenta o teor de potássio trocável e praticamente não altera cálcio mais magnésio trocáveis, causando com isso um aumento no valor de QAKe, permanecendo PTK inalterado (BECKETT, 1964b) .

Os dados referentes 'a influência da calagem são controversos. Alguns autores são unânimes em afirmar que a aplicação de calcário no solo reduz o valor de QAKe, não alterando o valor de potássio trocável, porém, diminuindo o de potássio planar, provocando com isso um aumento no poder ṫampão de potássio no solo (BECKETT, 1964b; MIRANDA e IGUE, 1972; KOCK et alii, 1970; GOEDERT et alii, 1975).

Como exemplo podem ser citados os dados apresentados por MIELNICZUK (1977) referentes ao PTK e QAKe de um Latossol Vermelho Escuro distrófico do : Brasil Central (LVEd) e de um Latossol Roxo distrófico do Rio Grande do Sul (Santo Angelo - LRd). Os dois solos, recebendo calagem para pH 6,0, tiveram seus valores de PTK aumentados de 0,08 para 0,24 e 0,84 para $1,35 \mathrm{meq} / 100 \mathrm{~g} /(\mathrm{mmol} / 1)^{1 / 2}$, respectivamente. Quanto aos valores de QAKe, foram reduzidos de 0,75 para 0,24 no LVEd e de 0,23 para $0,075(\operatorname{mmol} / 1)^{1 / 2}$ no LRd. 
O aumento do PTK representa um aumento de ca pacidade de adsorção de potássio pelos solos e, consequentemente, redução de perdas do elemento.

Em alguns solos da região cacueira da Bahia, como Nazaré (Ultissol), a calagem aumentou o teor de potássio planar diminuindo o QAKe e não teve efeito sobre estes parâmetros nos solos Itamirim (Vértissol) e Hidromórfico . Quanto ao teor de potássio trocável total, não foi alterado em nenhum solo, tendo sido, porem, o PTK modificado (MIRANDA e IGUE, 1972).

KOCK et alii. (1970), acreditam que a calagem provoca uma diminuição no grau de disponibilidade de potássio para as plantas mas não na quantidade de potássio dispo nível.

Em estudos feitos por BECKETT (1964b), a res peito da relação $Q / I$ de treze solos diferentes, foi constatada uma variação de dez e cinco vezes nos valores de PTK e QAKe respectivamente, estando os mesmos em tọno de 14 a. 120 $\left(\right.$ meq/100 q) $/(\text { mmol/l })^{1 / 2}$ para PTK e 0,005 a $0,025(\mathrm{~mol} / 1)^{1 / 2}$ para O QAKe. 
Solos da região cacaueira da Bahia, analisados por MIRANDA e IGUE (1972) apresentaram valores de QAKe desde $0,14 \times 10^{-2}$ até $0,60 \times 10^{-2}(\mathrm{~mol} / 1)^{1 / 2}$, os quais assemelham-se aos de alguns solos de Gana, $0,2 \times 10^{-2}$ a $0,6 \mathrm{x}$ $x 10^{-2}(\mathrm{~mol} / 1)^{1 / 2}$ obtidos por ÁCQUAYE et alii (1967).

GRAHM e FOX (1971), avaliando o parâmetro QAKe para onze séries de solos das ilhas Oahu e Havai, encontraram valores na faixa de $0,07 \times 10^{-2}$ a $0,7 \times 10^{-2}(\mathrm{~mol} / 1)^{1 / 2}$. Trabalhando com solos de Portugal GAMA (1966) encontrou que esse parâmetro variava de $0,19 \times 10^{-2}$ a $0,71 \times 10^{-2}(\mathrm{~mol} / 1)^{1 / 2}$.

- O solo Aceguá (Vertissol), no Rio Grande do Sul, possui QAKe e PTK iguais a $0,759(\mathrm{mmol} / 1)^{1 / 2}$ e 1,14 $(\mathrm{meq} / 100 \mathrm{~g}) /(\mathrm{mmol} / 1)^{1 / 2}$, respectivamente, e um apreciāvel re servatório de potássio, indicado pelos valores de potássio planar $(0,86 \mathrm{meq} / 100 \mathrm{~g})$ e potássio sujeito a equilíbrio com a solução $(1,23 \mathrm{meq} / 100 \mathrm{~g})$. Ao contrário, solos da mesma região, desenvolvidos de basalto, apresentam baixo poder tampão, estando com isso o potássio trocável, que é sujeito a equilíbrio, facilmente liberado para a solução do solo causando o empobrecimento deste (GOEDERT et alii, 1975). 
De maneira geral, pode se dizer que solos poụ co desenvolvidos, pouco lixiviados, com grande reserva de po tássio trocável, são aqụeles que também possuem maior quantị dade de cargas negativas na superfície dos colóides. Estes solos apresentam, relativamente, baixo valor de quociente de atividade de potássio (QAK) devido 'a baixa concentração do elemento na solução do solo e alto valor de poder tampão (PTK) (GRAHAM e FOX, 1971).

Segundo GAMA (1966), quando se compara valo res de QAKe com os seus respectivos valores de PTK,observa-se uma tendência para que os solos com quocientes de atividade de potássio em equilỉbrio mais elevados, possuam poder tampão relativamente baixo, isto é, as intensidades iniciais de po- . tássio variam inversamente com os valores de PTK.

Quando se analisa diversos solos, a compara çao entre os valores de seus parâmetros obtidos a partir das curvas Q/I deve ser feita com muita cautela: Conforme GOEDERT et alii. (1975), ela só é possível quando os solos apresentarem semelhantes teores de cálcio mais magnésio trocá veis, o que geralmente é difícil porque o reservatório de cátions trocáveis varia qualitativa e quantitativamente. 
Apesar do exposto, o conhecimento da relação Q/I dos solos é de grande valia porque através dele os solos podem ser manejados do ponto de vista da fertilidade, com maior segurança. 
Com a finalidade de se alcançar os objetivos propostos, foram avaliados o estado e a dinâmica do potássio nos solos, através do estudo de adsorção do elemento e da re lação Quantidade/Intensidade.

\subsection{Solos}

Os solos estudados neste trabalho sao da região dos Cariris, localizada no Estado da Paraíba e diferenciam-se tanto pelo seu material de origem quanto pelas suas características físicas e químicas. Foram identificados de acordo com a Classificação Brasileira de Solos (CAMARGo e BENNEMÀ, 1966), em:

1. Vertissol (V);

2. Planossol Solōdico (PL); 


\section{Bruno Não Cálcico (NC); \\ 4. Solonetz Solodizado (SS); \\ 5. Bruno Não Cálcỉco-vértico (NCv).}

As amostras de terra foram coletadas dos hor $\underline{i}$ zontes A e B ou A e C, secas ao ar, destorroadas e em seguida pas sadas por uma peneira com malha de $2 \mathrm{~mm}$.

Nas Tabelas 1 e 2 são apresentadas as caracte rísticas mineralógicas, física e química de cada solo.

\subsection{Adsorção de potássio}

As amostras de terra foram tratadas com soluções de concentração crescente de potássio. Estas foram preparadas com solução estoque de $\mathrm{KCl} 0,2 \mathrm{M}$ de tal maneira a serem obtidos seis ou mais diferentes níveis de potássio, apresentą dos nas Tabelas de 3 a 7 no capítulo Résultados e Discussão.

Em tubo de centrífuga de $50 \mathrm{ml}$, contendo $3 \mathrm{~g}$ de TFSA, foram adicionados $30 \mathrm{ml}$ de solução de tratamento, além da solução de referência, sem potássio. As amostras foram então agitadas durante uma hora, tempo considerado suficiente'para o equilíbrio, e em seguida centrifugadas, obten- 


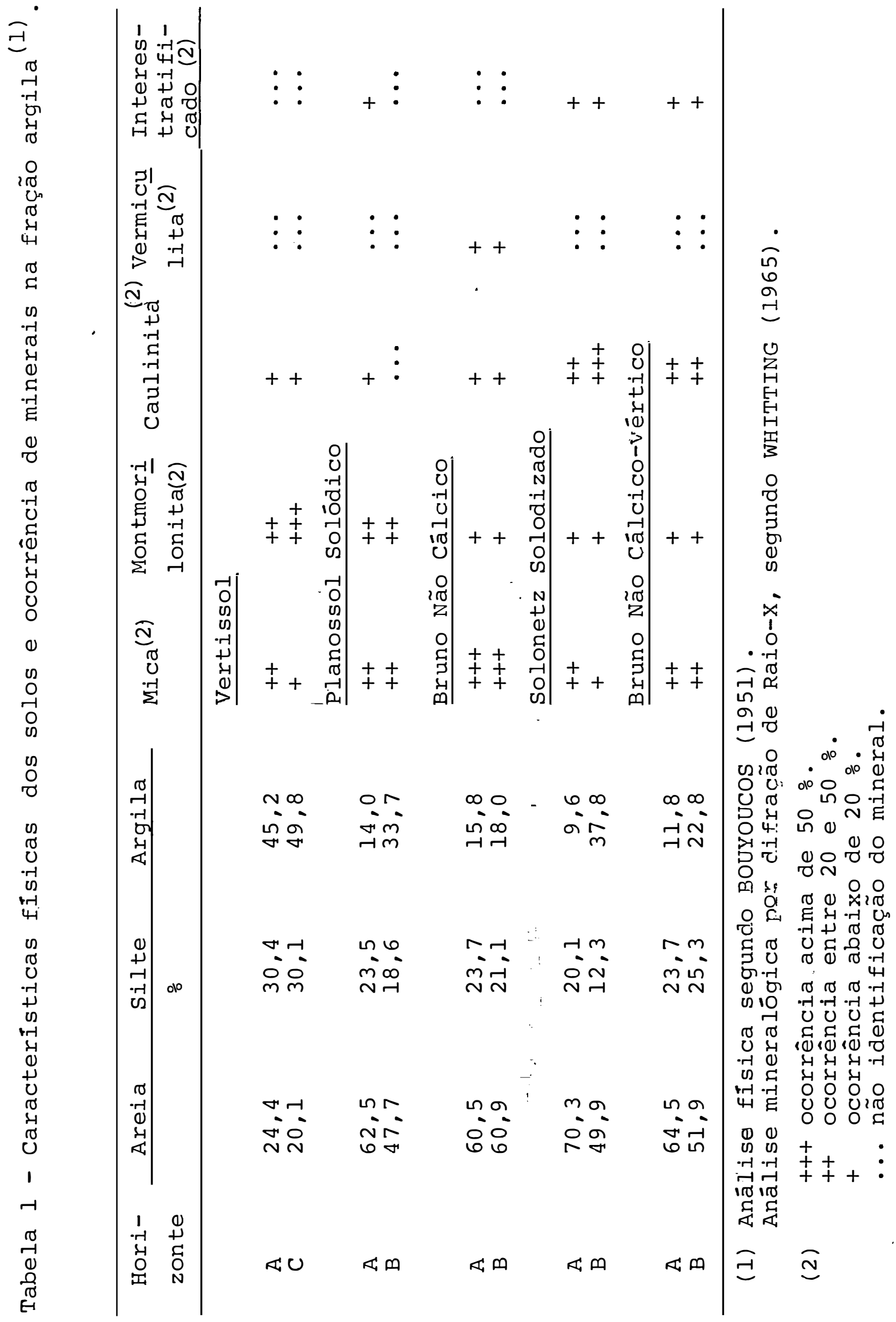




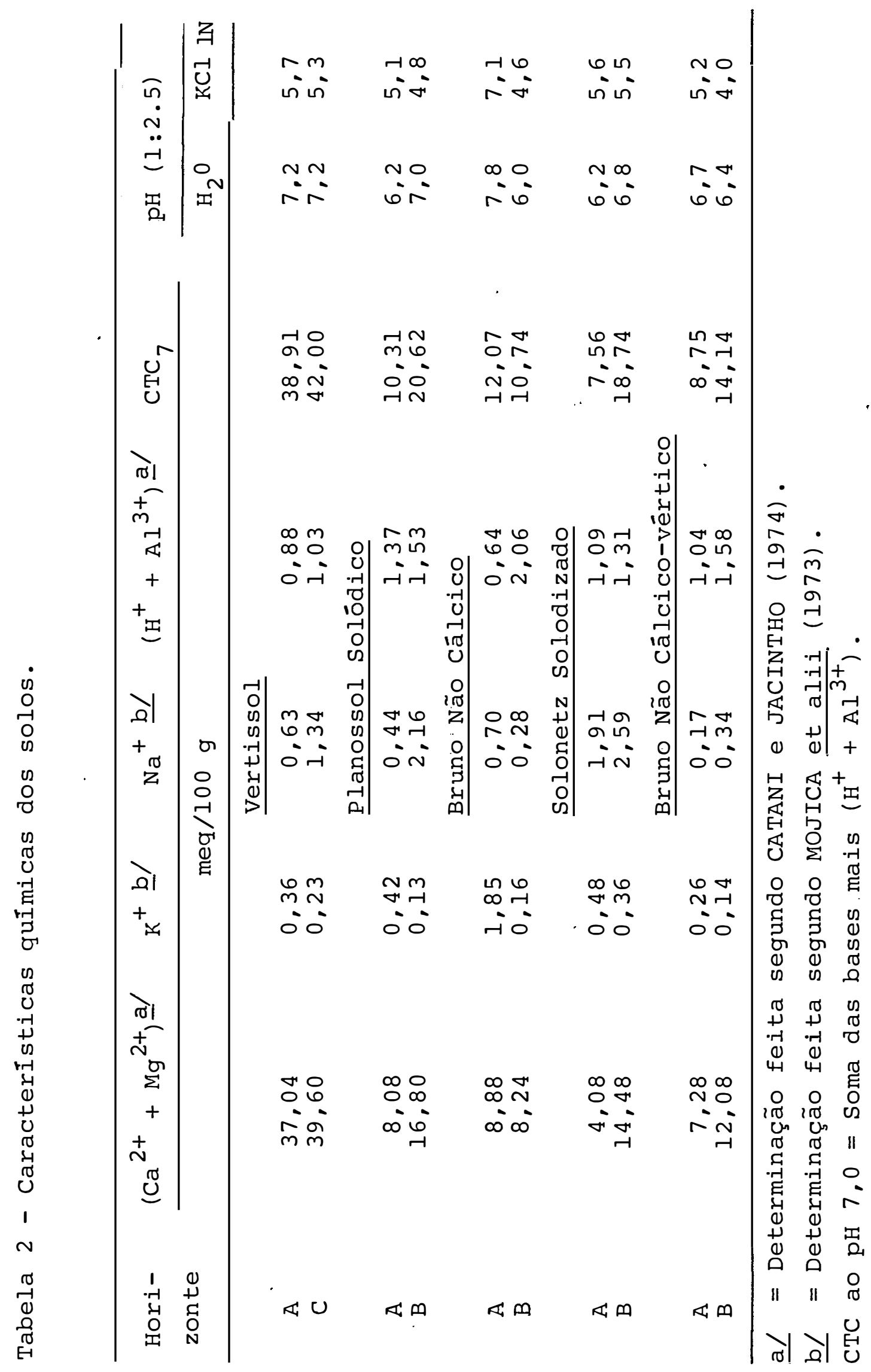


do-se assim, solução sobrenadante para análise. o potássio e o sódio dessa solução foram determinados por fotometria de chama, e o cálcio mais magnésio por quelatometria,utilizando o EDTA.

Pela diferença entre as concentrações de potássio antes e depois da agitação da suspensão, determinouse a quantidade de potássio adsorvido ou dessorvido pelo solo. $( \pm \Delta K)$. Os demais cátions encontrados na solução sobrenadante foram considerados deslocados pelo potássio no momen to da adsorção.

Para se avaliar a adsorção preferencial do potássio pelos solos, utilizou-se a equação de Gapon, que rela ciona a razão entre a concentração dos cátions potássio, cálcio e magnésio trocáveis, eđn a razão entre a concentração dos mesmós em solução. Assim,

$$
\begin{aligned}
& \frac{[\mathrm{KX}]}{\left[\mathrm{Ca}_{1 / 2} \mathrm{x}+\mathrm{Mg}_{1 / 2} \mathrm{x}\right]}=\mathrm{K}_{\mathrm{GK}}-\mathrm{Ca} \frac{\left[\mathrm{K}^{+}\right]}{\left[\mathrm{Ca}^{2+}+\mathrm{Mg}^{2+}\right]^{1 / 2}} \text {, onde: } \\
& {[\mathrm{KX}]=\mathrm{K}^{+} \text {trocável, meq/100 } \mathrm{g}} \\
& {\left[\mathrm{Ca}_{1 / 2} \mathrm{x}+\mathrm{Mg}_{1 / 2} \mathrm{x}^{\mathrm{x}}\right]=\mathrm{Ca}^{2+} \mathrm{e} \mathrm{Mg}^{2+} \text { trocáveis, meq/100 g }} \\
& \left|\mathrm{K}^{+}\right| \cdot=\mathrm{K}^{+} \text {na solução de equilíbrio, mmol/l } \\
& {\left[\mathrm{Ca}^{2+}+\mathrm{Mg}^{2+}\right]=\mathrm{Ca}^{2+} \text { e } \mathrm{Mg}^{2+} \text { na solução de equilíbrio, }} \\
& \text { mmol/1 } \\
& \mathrm{K}_{\mathrm{G} \mathrm{K}-\mathrm{Ca}}=\text { constante de Gapon, }(\operatorname{mmol} / 1)^{1 / 2} \text {. }
\end{aligned}
$$


3.3. Relação Quantidade/Intensidade de potássio no solo

O método de determinação da relação Q/I de potássio no solo, que diz respeito à relação entre $\mathrm{K}^{+}$trocável e $\mathrm{K}^{+}$na solução, foi baseádo no trabalho de GOEDERT et alii (1975), tendo sofrido algumas modificações.

As soluções de tratamento foram preparadas a partir de soluções estoques de $\mathrm{KCl} 0,2 \mathrm{M}$ e de $\mathrm{CaCl}_{2}$ 0,2 $\mathrm{M}$, tendo mesma concentração de cálcio (2 mmol/l) e diferentes níveis de potássio, cujas concentrações são apresentadas nas Tabelas de 8 a 12 no capítulo Resultados e Discussão.

Em tubo de centrífuga, de $50 \mathrm{ml}$, contendo $3 \mathrm{~g}$ de TFSA, foram adicionados $30 \mathrm{ml}$ de cada solução de trata mento, sendo uma solução de referência, sem potássio, adicio nada à menores quantidades de amostras, como 0,$3 ; 0,8$ e 1,5 g, a fim de se obter baixos valores de $\Delta K$ e de QAK. As amos tras foram então agitadas durante uma hora e em seguida centrifugadas, obtendo-se a solução sobrenadante (solução de equilíbrio) para análise. Os cátions, cálcio, magnésio e potássio foram determinados conforme já descrito no item 3.2 .1 . 
A partir das fórmulas seguintes, determinouse as concentrações de $\mathrm{K}^{+}$e $\left(\mathrm{Ca}^{2+}+\mathrm{Mg}^{2+}\right)$ das soluções de equilíbrio:

$$
\left[\mathrm{K}^{+}\right]=\mathrm{L} \times 5 \times 10^{-3} \times \mathrm{f} \quad \text { onde: }
$$

$\left[\mathrm{K}^{+}\right]=$concentração de $\mathrm{K}^{+}$da solução de equilíbrio,mmol/l

L = leitura da solução de quilỉbrio.

$5 \times 10^{-3}=\frac{5 \times 10^{-4}}{100} \times 10^{3}$, mmol/l. A solução padrão de $\mathrm{K}^{+}$foi de $5 \times 10^{-4} \mathrm{M}$

f = fator de diluição da solução de equilíbrio..

$$
\left[\mathrm{Ca}^{2+}+\mathrm{Mg}^{2+}\right]=\left(\mathrm{V}_{1}-\mathrm{V}_{2}\right) \quad \text { onde: }
$$

$\left[\mathrm{Ca}^{2+}+\mathrm{Mg}^{2+}\right]=$ concentração de $\left(\mathrm{Ca}^{2+}+\mathrm{Mg}^{2+}\right)$ da solução de equilíbrio, mol/l.

$\mathrm{v}_{1}=$ volume de EDTA $\cdot 0,01 \mathrm{M}$ gasto na titulação da solução de equilíbrio, ml.

$\mathrm{v}_{2}=$ vol-ume de EDTA $0,01 \mathrm{M}$ gasto na titulação da solução de $\mathrm{MgCl}_{2} 0,0025 \mathrm{M}, \mathrm{ml}$.

A adsorção ( $\Delta K$ positivo) ou dessorção ( $\Delta K$ negativo) de potássio pelos solos foi determinada a partir das concentrações do elemento nas soluções de tratamento e equilíbrio, conforme a equação: 
$\Delta \mathrm{K}(\mathrm{meq} / 100 \mathrm{~g})=\left(\mathrm{c}_{1}-\mathrm{c}_{2}\right) \times \frac{3}{\mathrm{TFSA}} \quad$ onde $:$

$c_{1}=$ concentração de potássio na solução de tratamento, mmol/l.

$c_{2}=$ concentração de potássio na solução de equilíbrio , $\mathrm{mmol} / \mathrm{l}$.

$3=0,0301$ de solução de tratamento $\times 100 \mathrm{~g}$ de TFSA.

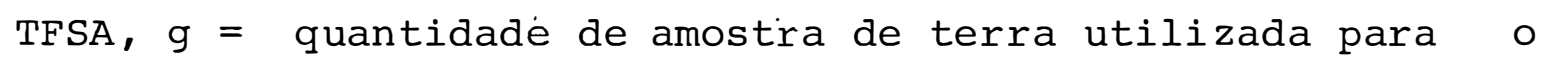
equilíbrio.

O QAK (quociente de atividade de potássio), se gundo MIELNICZUK (1980), foi calculado a partir das concen trações de $\mathrm{K}^{+}$e de $\left(\mathrm{Ca}^{2+}+\mathrm{Mg}^{2+}\right)$ da solução de equilíbrio, uma vez que estas, por serem muito baixas, são semelhantes as atividades dos elementos. Assim,

$$
\mathrm{QAK}=\frac{\left(\mathrm{K}^{+}\right)}{\left(\mathrm{Ca}^{2+}+\mathrm{Mg}^{2+}\right) \mathrm{I/2}}
$$

onde :

$\mathrm{QAK}=$ quociente de atividade de potássio, $(\mathrm{mmol} / \mathrm{l})^{1 / 2}$ $\left(\mathrm{K}^{+}\right)=$concentração de potássio da solução de equilíbrio , $\mathrm{mmol} / \mathrm{l}$. 
$\left(\mathrm{Ca}^{2}+\mathrm{Mg}^{2+}\right)=$ concentração de cálcio mais magnésio da solução de equilíbrio, mmol/l.

Com os dados de $\Delta K$ e QAK para cada amostra de terra, foram construidos gráficos (Q/I) a partir dos quais determinou-se os parâmetros QAKe, Ke e PTK, sendo QAKe (quociente de atividade de equilíbrio) o valor de QAK quando K for igual a zero; Ke (atividade de equilíbrio de potássio na solução do solo) calculado multiplicando-se QAKe pela raiz quadrada da concentração de cálcio mais magnésio em equi líbrio, para $\Delta \mathrm{K}$ igual a zero, ou seja, $\left(\mathrm{Ca}^{2+}+\mathrm{Mg}^{2+}\right)^{1 / 2} \mathrm{e}$; PTK (poder tampão de potássio) obtido em qualquer trecho da parte linear da curva $Q / I$, pois corresponde a inclinação da mesma. 
4. RESULTADOS E DISCUSSÃO

4.1. Adsorção de potássio

Com o fornecimento de. doses crescentes de potássio aos solos, através das soluções de tratamento, estes deixaram de dessorver o elemento ( $\Delta K$ negativo), passando a adsorvê-lo ( $\Delta \mathrm{K}$ positivo). Simultaneamente, por ser a adsorção basicamente um processo de troca catiônica, ocorreu a dessorção de outros cátions, como cálcio, magnésio e sódio (Tabelas 3, 4, 5, 6 e 7).

Conforme mostra a Figura 2, os solos se comportam de maneira diferențe quanto 'a adsorção do potássio.Pâ ra uma mesma concentração do elemento na solução de equilí brio, por exemplo, 2,5 mol/l, os solos apresentam quantidades diferentes de potássio adsorvido, no caso, variando de 
0,35 a 6,35 me/100 g de terra. De maneira geral, pode-se di zer que nesse particular destacam-se dois grupos de amostras, sendo o primeiro formado pelos horizontes A do PL, NC, SS e $\mathrm{NCv}$ e horizonte $\mathrm{B}$ do NC e o segundo pelas demais amostras, as quais apresentam maiores valores de CTC e por isso maior adsoŕção de potássio.

A variação da adsorção de potássio que acompa nha, de certa maneira, a da CTC dos solos, é influenciada pe lo teor e tipo de argila presente nos mesmos. Assim, pelos dados correspondentes aos horizontes B do SS e NCv (Tabelas 1 e 2), observa-se que este adsorve mais potássio que aquele, provavelmente devido a composição mineralógica de sua fração argila. O horizonte $\mathrm{B}$ do $\mathrm{NCv}$ é mais rico em mica, enquanto que a mesma camada do SS, por sua vez, tem predominância de caulinita.

Outro caso da influência do tipo de argila so bre a adsorção de potássio pelos solos pode ser observado comparando-se valores de $\Delta \mathrm{K}$ dos horizontes $\mathrm{B}$ dos solos PL e SS. Este último apresenta maior poŕcentagem de argila que aquele, porém, sua menor СTC e consequentemente, menor adsor ção de potássio, são provavelmente devidos à predominância , em sua fração argila, do mineral caulinita. 
Tabela 3 - Concentração de potássio nas soluções de tratamen to e equilíbrio; variação do potássio trocável $(\Delta K)$; concentração de cálcio, magnésio e sódio dessorvidos; quantidade total de potássio trocá vel, no Vertissol (horizontes A e C).

\begin{tabular}{|c|c|c|c|c|c|}
\hline \multicolumn{2}{|c|}{$\mathrm{K}^{+}$, mmol/l } & \multirow{2}{*}{$\frac{\Delta \mathrm{K}}{m e q / 100 \mathrm{~g}}$} & $\left(\mathrm{Ca}^{2+}+\mathrm{Mg}^{2+}\right)$ & \multirow[t]{2}{*}{$\mathrm{Na}^{+}$} & \multirow{2}{*}{$\frac{\mathrm{K}^{+} \text {trocável }}{\text { meg } / 100 \mathrm{~g}}$} \\
\hline Tratamento & Equilíbrio & & mmo & & \\
\hline \multicolumn{6}{|c|}{ Horizonte A } \\
\hline $\begin{array}{l}0,000 \\
0,385 \\
1,017 \\
1,485 \\
1,952 \\
2,475 \\
2,970 \\
3,780 \\
4,830 \\
5,775 \\
7,280 \\
8,190 \\
9,165\end{array}$ & $\begin{array}{l}0,034 \\
0,094 \\
0,167 \\
0,241 \\
0,326 \\
0,455 \\
0,597 \\
0,975 \\
1,155 \\
1,575 \\
2,205 \\
2,730 \\
3,255\end{array}$ & $\begin{array}{r}-0,034 \\
0,291 \\
0,850 \\
1,244 \\
1,626 \\
2,020 \\
2,373 \\
2,805 \\
3,675 \\
4,200 \\
5,075 \\
5,460 \\
5,910\end{array}$ & $\begin{array}{r}0,10 \\
0,20 \\
0,45 \\
0,70 \\
0,90 \\
1,00 \\
1,25 \\
1,55 \\
1,90 \\
2,30 \\
2,40 \\
2,75 \\
2,90\end{array}$ & $\begin{array}{l}0,26 \\
0,32 \\
0,35 \\
0,38 \\
0,38 \\
0,38 \\
0,39 \\
0,40 \\
0,41 \\
0,42 \\
0,45 \\
0,47 \\
0,51\end{array}$ & $\begin{array}{l}0,33 \\
0,65 \\
1,21 \\
1,60 \\
1,99 \\
2,38 \\
2,73 \\
3,16 \\
4,03 \\
4,56 \\
5,43 \\
5,82 \\
6,27\end{array}$ \\
\hline \multicolumn{6}{|c|}{$\underline{\text { Horizonte C }}$} \\
\hline $\begin{array}{l}0,000 \\
0,385 \\
1,017 \\
1,485 \\
1,952 \\
2,475 \\
2,970 \\
3,780 \\
4,830 \\
5,775 \\
7,280 \\
8,190 \\
9,165\end{array}$ & $\begin{array}{l}0,025 \\
0,036 \\
0,059 \\
0,115 \\
0,180 \\
0,267 \\
0,371 \\
0,600 \\
0,840 \\
1,155 \\
1,785 \\
2,231 \\
2,625\end{array}$ & $\begin{array}{r}-0,025 \\
0,349 \\
0,959 \\
1,370 \\
1,772 \\
2,208 \\
2,599 \\
3,180 \\
3,990 \\
4,620 \\
5,495 \\
5,959 \\
6,540\end{array}$ & $\begin{array}{l}0,10 \\
0,20 \\
0,40 \\
0,60 \\
0,75 \\
1,00 \\
1,10 \\
1,40 \\
1,80 \\
2,20 \\
2,35 \\
2,70 \\
2,90\end{array}$ & $\begin{array}{l}0,34 \\
0,56 \\
0,63 \\
0,70 \\
0,75 \\
0,81 \\
0,77 \\
0,80 \\
0,79 \\
0,81 \\
1,03 \\
1,06 \\
1,08\end{array}$ & $\begin{array}{l}0,20 \\
0,58 \\
1,19 \\
1,60 \\
2,00 \\
2,44 \\
2,83 \\
3,41 \\
4,22 \\
4,85 \\
5,72 \\
6,19 \\
6,77\end{array}$ \\
\hline
\end{tabular}


Tabela 4 - Concentração de potássio nas soluções de tratamen to e equilíbrio; variação do potássio trocável

( $\Delta \mathrm{K})$; concentração de cálcio, magnésio e sōdio dessorvidos; quantidade total de potássio trocá vel no Planossol Solódico (horizontes A e B).

\begin{tabular}{|c|c|c|c|c|c|}
\hline \multicolumn{2}{|c|}{$\mathrm{K}^{+}, \mathrm{mmol} / \mathrm{l}$} & \multicolumn{2}{|c|}{$\Delta . K . \quad\left(\mathrm{Ca}^{2+}+\mathrm{Mg}^{2+}\right)$} & $\mathrm{Na}^{+}$ & \multirow{2}{*}{$\frac{\mathrm{K}^{+} \cdot \text { trocável }}{\text { meg } / 100 \mathrm{~g}}$} \\
\hline Tratamento & Equilíbrio & $\mathrm{meg} / 100 \mathrm{~g}$ & mtrmo & & \\
\hline \multicolumn{6}{|c|}{ Horizonte A } \\
\hline $\begin{array}{l}0,000 \\
0,385 \\
1,017 \\
1,485 \\
1,952 \\
2,475 \\
2,970 \\
3,612 \\
4,095 \\
5,224 \\
6,195 \\
7,395\end{array}$ & $\begin{array}{l}0,109 \\
0,390 \\
0,660 \\
0,997 \\
1,305 \\
1,691 \\
2,076 \\
2,585 \\
2,997 \\
3,832 \\
4,725 \\
5,617\end{array}$ & $\begin{array}{r}-0,109 \\
-0,005 \\
0,357 \\
0,487 \\
0,647 \\
0,784 \\
0,894 \\
1,027 \\
1,098 \\
1,392 \\
1,470 \\
1,778\end{array}$ & $\begin{array}{c}- \\
0,15 \\
0,10 \\
0,55 \\
0,55 \\
0,60 \\
0,60 \\
0,60 \\
0,65 \\
0,67 \\
0,80 \\
0,90\end{array}$ & $\begin{array}{l}0,22 \\
0,27 \\
0,28 \\
0,28 \\
0,29 \\
0,28 \\
0,28 \\
0,32 \\
0,31 \\
0,33 \\
0,34 \\
0,42\end{array}$ & $\begin{array}{l}0,31 \\
0,41 \\
0,78 \\
0,91 \\
1,07 \\
1,20 \\
1,31 \\
1,45 \\
1,52 \\
1,81 \\
1,89 \\
2,20\end{array}$ \\
\hline \multicolumn{6}{|c|}{ Horizonte B } \\
\hline $\begin{array}{l}0,000 \\
0,385 \\
1,017 \\
1,485 \\
1,952 \\
2,475 \\
2,970 \\
3,780 \\
4,830 \\
5,775 \\
7,280 \\
8,190 \\
9,165\end{array}$ & $\begin{array}{l}0,040 \\
0,041 \\
0,060 \\
0,156 \\
0,261 \\
0,360 \\
0,577 \\
0,892 \\
1,470 \\
1,942 \\
2,835 \\
3,412 \\
3,937\end{array}$ & $\begin{array}{r}-0,040 \\
0,344 \\
0,9,57 \\
1,328 \\
1,691 \\
2,115 \\
2,392 \\
2,888 \\
3,360 \\
3,833 \\
4,445 \\
4,778 \\
5,228\end{array}$ & $\begin{array}{l}0,20 \\
0,20 \\
0,15 \\
0,45 \\
0,50 \\
0,60 \\
0,65 \\
0,90 \\
-1,10 \\
1,50 \\
1,50 \\
1,90 \\
1,90\end{array}$ & $\begin{array}{l}0,63 \\
1,11 \\
1,39 \\
1,71 \\
1,69 \\
1,72 \\
1,83 \\
1,86 \\
2,11 \\
1,95 \\
2,14 \\
2,19 \\
2,23\end{array}$ & $\begin{array}{l}0,09 \\
0,47 \\
1,09 \\
1,46 \\
1,82 \\
2,24 \\
2,52 \\
3,02 \\
3,49 \\
3,96 \\
4,57 \\
4,91 \\
5,36\end{array}$ \\
\hline
\end{tabular}


Tabela 5 - Concentração de potássio nas soluções de tratamen to e equilíbrio; variação do potássio trocável

$(\Delta K)$; concentração de cálcio, magnésio e sōdio dessorvidos; quantidade total de potássio trocável no Bruno Não Cálcico (horizonte A e B).

\begin{tabular}{|c|c|c|c|c|c|c|}
\hline $\mathrm{K}^{+}$ & $1 / 1$ & $\Delta . \mathrm{K}$ & $\left(\mathrm{Ca}^{2+}+\mathrm{Mg}^{2+}\right)$ & $\mathrm{Na}^{+}$ &. $\mathrm{K}^{+} \cdot \operatorname{tro}$ & ável \\
\hline Tratamento & Equilỉbrio & meg/100 g & mImo: & & $\mathrm{meg} / 100$ & $\mathrm{~g}$ \\
\hline
\end{tabular}

Horizonte A

$\begin{array}{llllll}0,000 & 0,605 & -0,605 & 0,20 & 0,52 & 1,24 \\ 0,385 & 0,915 & -0,530 & 0,30 & 0,52 & 1,32 \\ 1,017 & 1,305 & -0,288 & 0,30 & 0,51 & 1,56 \\ 1,485 & 1,635 & -0,150 & 0,50 & 0,53 & 1,70 \\ 1,952 & 1,957 & -0,005 & 0,65 & 0,54 & 1,84 \\ 2,475 & 2,227 & 0,248 & 0,60 & 0,52 & 2,10 \\ 2,970 & 2,614 & 0,356 & 0,60 & 0,53 & 2,21\end{array}$

Horizonte B

$\begin{array}{llllll}0,000 & 0,135 & -0,135 & - & 0,13 & 0,02 \\ 0,385 & 0,256 & 0,128 & 0,20 & 0,13 & 0,29 \\ 1,017 & 0,412 & 0,604 & 0,25 & 0,15 & 0,76 \\ 1,485 & 0,720 & 0,765 & 0,45 & 0,15 & 0,92 \\ 1,952 & 0,967 & 0,985 & 0,55 & 0,15 & 1,14 \\ 2,475 & 1,282 & 1,192 & 0,70 & 0,15 & 1,35 \\ 2,970 & 1,664 & 1,306 & 0,70 & 0,14 & 1,47 \\ 3,780 & 2,319 & 1,470 & 0,95 & 0,16 & 1,63 \\ 4,830 & 3,307 & 1,523 & 0,90 & 0,17 & 1,68\end{array}$


Tabela 6 - Concentração de potássio nas soluções de tratamento e equilíbrio; variação do potássio trocável $(\Delta K)$; concentração de cálcio, magnésio e sódio dessorvidos; quantidade total de potássio trocável no Solonetz Solodizado (horizontes A e B).

\begin{tabular}{|c|c|c|c|c|c|}
\hline \multicolumn{2}{|c|}{$\mathrm{K}^{+}, \mathrm{mmol} / \mathrm{l}$} & \multirow{2}{*}{$\frac{\Delta \mathrm{K}}{\text { meg/100g }}$} & $\left(\mathrm{Ca}^{2+}+\mathrm{Mg}^{2+}\right)$ & \multirow[t]{2}{*}{$\mathrm{Na}$} & \multirow{2}{*}{$\frac{\mathrm{K}^{+} \text {trocável }}{\text { meq } / 100 \mathrm{~g}}$} \\
\hline Tratamento & Equilíbrio & & $\mathrm{mmol} / \mathrm{l}$ & & \\
\hline \multicolumn{6}{|c|}{ Horizonte A } \\
\hline $\begin{array}{l}0,000 \\
0,385 \\
1,017 \\
1,485 \\
1,952 \\
2,475 \\
2,970 \\
3,612 \\
4,095 \\
5,224 \\
6,195 \\
7,395 \\
8,602 \\
9,687\end{array}$ & $\begin{array}{l}0,236 \\
0,570 \\
0,915 \\
1,305 \\
1,612 \\
2,076 \\
2,505 \\
3,135 \\
3,675 \\
4,646 \\
5,565 \\
6,510 \\
7,617 \\
8,563\end{array}$ & $\begin{array}{r}-0,236 \\
-0,185 \\
0,102 \\
0,180 \\
0,340 \\
0,400 \\
0,465 \\
0,477 \\
0,420 \\
0,578 \\
0,630 \\
0,885 \\
1,085 \\
1,124\end{array}$ & $\begin{array}{l}0,10 \\
0,20 \\
0,15 \\
0,35 \\
0,35 \\
0,40 \\
0,55 \\
0,40 \\
0,45 \\
0,50 \\
0,50 \\
0,55 \\
0,55 \\
0,60\end{array}$ & $\begin{array}{l}1,95 \\
2,04 \\
2,07 \\
2,14 \\
1,96 \\
1,98 \\
1,98 \\
2,28 \\
2,28 \\
2,29 \\
2,31 \\
2,40 \\
2,34 \\
2,37\end{array}$ & $\begin{array}{l}0,24 \\
0,29 \\
0,58 \\
0,66 \\
0,82 \\
0,88 \\
0,94 \\
0,96 \\
0,90 \\
1,06 \\
1,11 \\
1,36 \\
1,56 \\
1,60\end{array}$ \\
\hline \multicolumn{6}{|c|}{$\underline{\text { Horizonte B }}$} \\
\hline $\begin{array}{l}0,000 \\
0,385 \\
1,017 \\
1,485 \\
1,952 \\
2,475 \\
2,970 \\
3,612 \\
4,095 \\
5,224 \\
6,195 \\
7,395 \\
8,602 \\
9,687\end{array}$ & $\begin{array}{l}0,212 \\
0,332 \\
0,435 \\
0,810 \\
0,952 \\
1,057 \\
1,389 \\
1,925 \\
2,131 \\
2,681 \\
3,272 \\
4,121 \\
4,777 \\
5,696\end{array}$ & $\begin{array}{r}-0,212 \\
0,052 \\
0,582 \\
0,675 \\
0,999 \\
1,417 \\
1,581 \\
1,687 \\
1,964 \\
2,543 \\
2,923 \\
3,274 \\
3,825 \\
3,991\end{array}$ & $\begin{array}{l}0,35 \\
0,30 \\
0,35 \\
0,70 \\
0,55 \\
0,70 \\
0,80 \\
0,87 \\
0,85 \\
1,07 \\
1,20 \\
1,25 \\
1,45 \\
1,60\end{array}$ & $\begin{array}{l}1,92 \\
2,11 \\
2,11 \\
2,31 \\
2,16 \\
2,25 \\
2,37 \\
2,56 \\
2,59 \\
2,59 \\
2,68 \\
2,70 \\
2,77 \\
2,65\end{array}$ & $\begin{array}{l}0,15 \\
0,41 \\
0,94 \\
1,03 \\
1,36 \\
1,78 \\
1,94 \\
2,05 \\
2,32 \\
2,90 \\
3,28 \\
3,63 \\
4,18 \\
4,35\end{array}$ \\
\hline
\end{tabular}


Tabela 7 - Concentração de potássio nas soluções de tratamen to e equilíbrio; variação do potássio trocável $(\Delta K)$; concentração de cálcio, magnésio e sódio dessorvidos; quantidade total de potássio trocável no Bruno Não cálcico-vértico (horizontes A e B) •

\begin{tabular}{|c|c|c|c|c|}
\hline $\mathrm{K}^{+}, \mathrm{mmol} / \mathrm{l}$ & $\Delta K$ & $\left(\mathrm{Ca}^{2+}+\mathrm{Mg}^{2+}\right)$ & $\mathrm{Na}^{+}$ & $\mathrm{K}^{+}$trocavel \\
\hline Tratamento Equilíbrio & meq $/ 100 \mathrm{~g}$ & пाто & & meq/100 g \\
\hline
\end{tabular}

Horizonte A

$\begin{array}{llrlll}0,000 & 0,176 & -0,176 & - & 0,05 & 0,08 \\ 0,385 & 0,351 & 0,034 & 0,10 & 0,07 & 0,29 \\ 1,017 & 0,652 & 0,565 & 0,15 & 0,07 & 0,62 \\ 1,485 & 0,900 & 0,585 & 0,40 & 0,06 & 0,84 \\ 1,952 & 1,110 & 0,842 & 0,70 & 0,06 & 1,10 \\ 2,475 & 1,581 & 0,894 & 0,70 & 0,06 & 1,15 \\ 2,970 & 1,855 & 1,115 & 0,70 & 0,06 & 1,37 \\ 3,780 & 2,467 & 1,313 & 0,80 & 0,06 & 1,57 \\ 4,830 & 3,465 & 1,365 & 0,90 & 0,06 & 1,62 \\ 5,775 & 4,226 & 1,549 & 1,00 & 0,07 & 1,81 .\end{array}$

Horizonte B

$\begin{array}{lrrrrr}0,000 & 0,145 & -0,145 & - & 0,13 & - \\ 0,385 & 0,215 & 0,170 & 0,10 & 0,18 & 0,31 \\ 1,017 & 0,225 & 0,792 & 0,20 & 0,20 & 0,93 \\ 1,485 & 0,390 & 1,095 & 0,60 & 0,20 & 1,23 \\ 1,952 & 0,487 & 1,465 & 0,90 & 0,20 & 1,60 \\ 2,475 & 0,652 & 1,822 & 0,90 . & 0,20 & 1,96 \\ 2,970 & 0,907 & 2,062 & 1,05 & 0,20 & 2,20 \\ 3,780 & 1,338 & 2,442 & 1,30 & 0,20 & 2,58 \\ 4,830 & 2,021 & 2,809 & 1,50-\therefore & 0,23 & 2,95 \\ 5,775 & 2,598 & 3,177 & 1,60 & 0,24 & 3,32 \\ 7,280 & 3,412 & 3,868 & 1,90 & 0,25 & 4,01\end{array}$




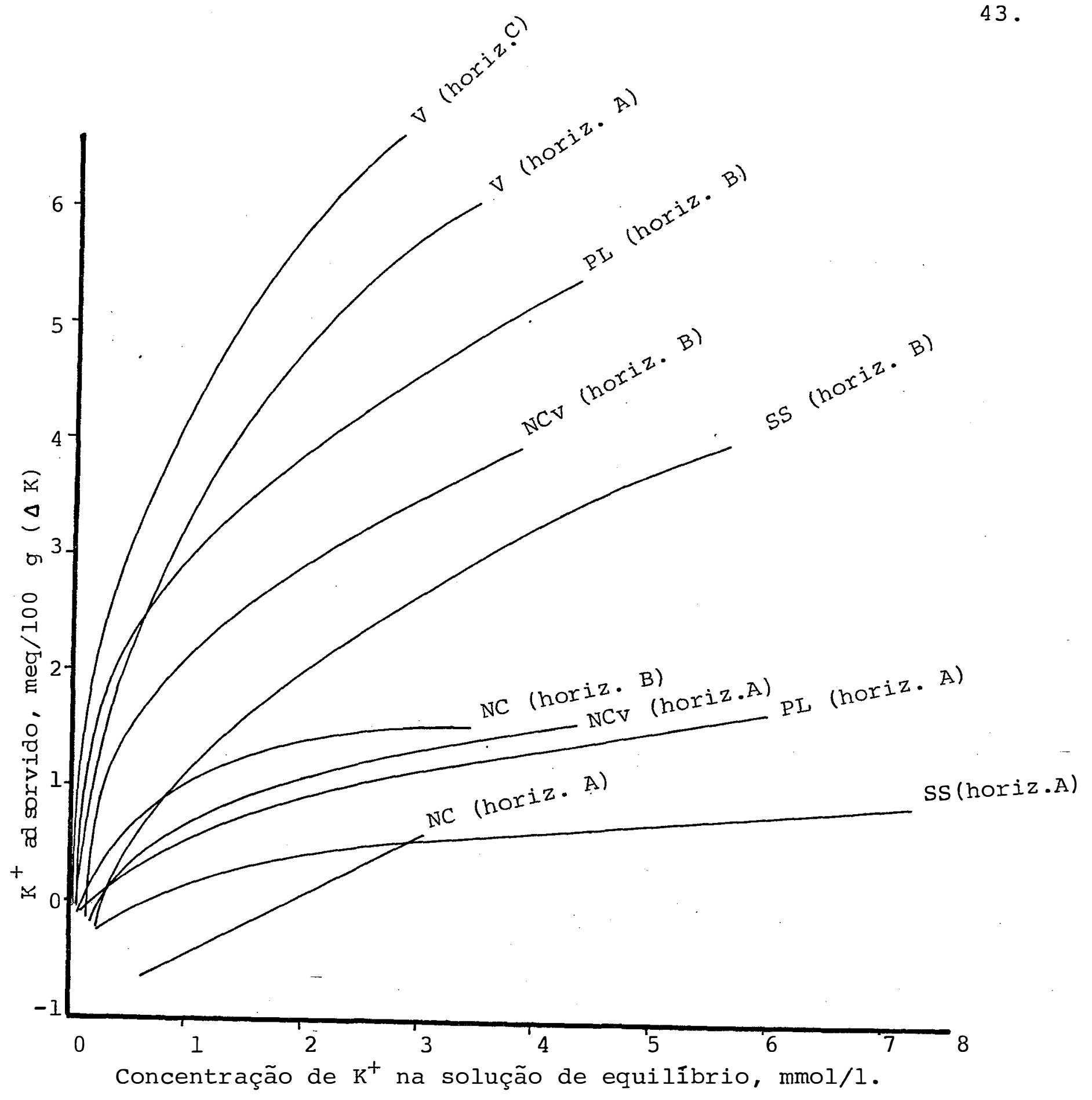

Figura 2 - Variação do potássio adsorvido em função da concentração do elemento na solução de equilíbrio do Vertissol (V), Planossol Solódico (PL), Bruno Não Cálcico (NC), Solonetz Solodizado (SS) e Bruno Não Cálcico-vértico ( $\mathrm{NCv})$. 
A diferença de comportamento entre os horizon tes do solo NCv, quanto 'a adsorção de potássio, é talvez decor rente dos diferentes teores de argila que apresentam,jā que a cormosição mineralógica desses horizontes é semelhante. O horizonte A tendo menor porcentagem de argila e CTC, apresenta menor adsorção de potássio qué o horizonte $B$.

A saturação inicial em potássio pelos solos, constitui outro fator de influência na adsorção do elemento. Esta varia de modo inverso àquela, tanto que a distribuição das curvas na Figura 2, do horizonte C do V ao. horizonte A do NC, corresponde à sequência crescente da porcentagem de saturação em potássio dos solos.

As relações entre a concentração de potássio na solução de equilíbrio e a quantidade total de potássio trocável (potássio adsorvido pelo solo mais o da forma trocá vel antes do equilíbrio) são apresentadas na Figura 3.As cur vas descrevem una função do tipo potência e, conforme o solo, apresentam inclinações diferentes e variāveis. Estas varia ções são devidas às relações . K $\mathrm{K}$ trocāvel/Kं solução mantidas pelos solos, as quais correspondem ao poder tampão de potássio (PTK) . 


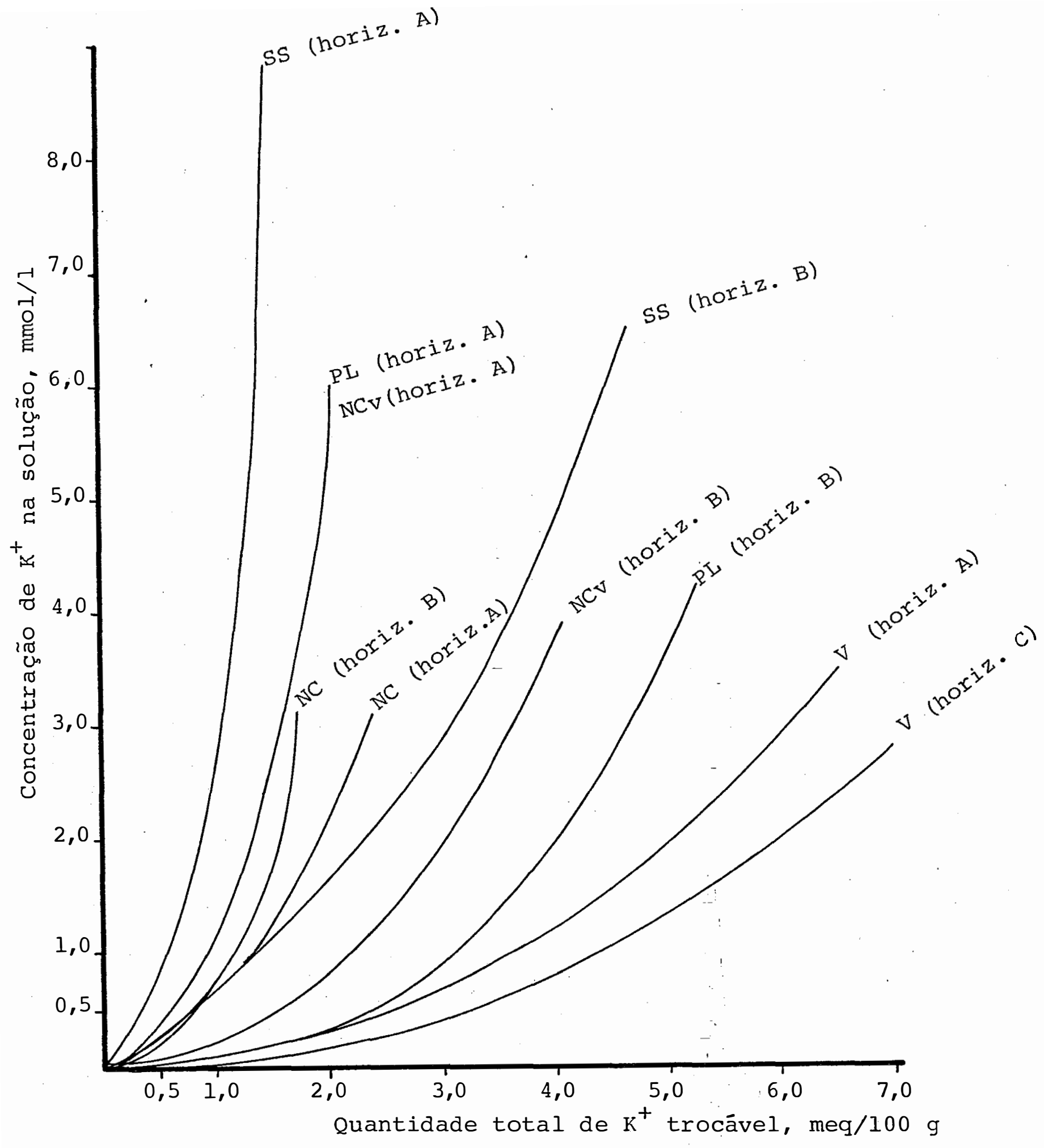

Figura 3 - Relação entre concentração de potássio na solução de equilíbrio e a quantidade total de potássio trocável no Vertís sol (V), Planossol Solódico (PL), Bruno Não Cálcico (NC) , Solonetz Solodizado (SS) e Bruno Não Cálcico-vértico (NCv). 
Conforme a Figura 3, o horizonte $\mathrm{C}$ do $\mathrm{V}$ e horizonte A do SS, possuem respectivamente, o maior e o menor va lor de PTK dentre todas as amostras de solo. Isto equivale a dizer que, para uma mesma redução de $\mathrm{K}$ trocável nos dois solos, a variação na concentração do $\mathrm{K}$ solução no ss (hori zonte A), será maior que no $V$ (horizonte $C$ ). Observa-se, pela mesma figura, que a variação do PTK dos solos acompanha a da CTC à pH 7,0 dos mesmos (Tabela 2), concordando com o exposto por MIELNICZUK (1980).

Para um mesmo solo, pode-se dizer que a concentração de potássio da solução correlaciona bem com a quantidade de potássio trocável, isto é, para cada valor des te corresponde um determinado daquele. Porém, comparando- se diferentes solos, nota-se que para manterem um mesmo valor de potássio na solução, os solos precisam ter diferentes teo res de potássio trocável (Figura 3).

A Fịgura 4 mostra um melhor critério a ser utilizado quando se compara vários solos, isto é, a relação entre a concentração de potássio da solução de equilíbrio e a porcentagem de saturação em potássio. Apesar destas também serem diferentes para cada solo, para uma mesma concentração de potássio na solução, variam menos que oṣ valores de potás 
sio trocável, o que é evidenciado na figura pela proximidade das curvas.

A variação na porcentagem de saturação em potássio trocável pode ser relacionada à porcentagem de argila dos 'solos, 'a sua composição mineralógica e, algumas vezes, à presença de sódio no complexo sortivo dos mesmos. Assim, a necessidade de uma maior porcentagem de saturação em potás sio apresentada pelo horizonte B do PL, para manter uma determinada concentração do elemento na solução de equilíbrio (Figura 4), pode ser causada por sua alta saturação inicial em sódio e baixa em potássio (Tabela 2), já que as outras cạ racteristicas do horizonte não o destacam dos demais.

$\overline{\mathrm{A}}$ respeito do horizonte $\mathrm{B}$ do SS, apesar de apresentar alta porcentagem de saturação em sódio, sua curva mostra uma menor porcentagem de saturação em potássio; o que pode ser explicado, neste caso, devido 'a predominância de caulinita em sua fração argila. Este tipo de mineral apresen ta baixa adsorção de potássio, o que faz com que a maior parte do elemento fornecido ao solo permaneça em solução

Quanto ao horizonte A do NC, apesar de apresentar alta saturação em potássio, mantém, inicialmente, bai 


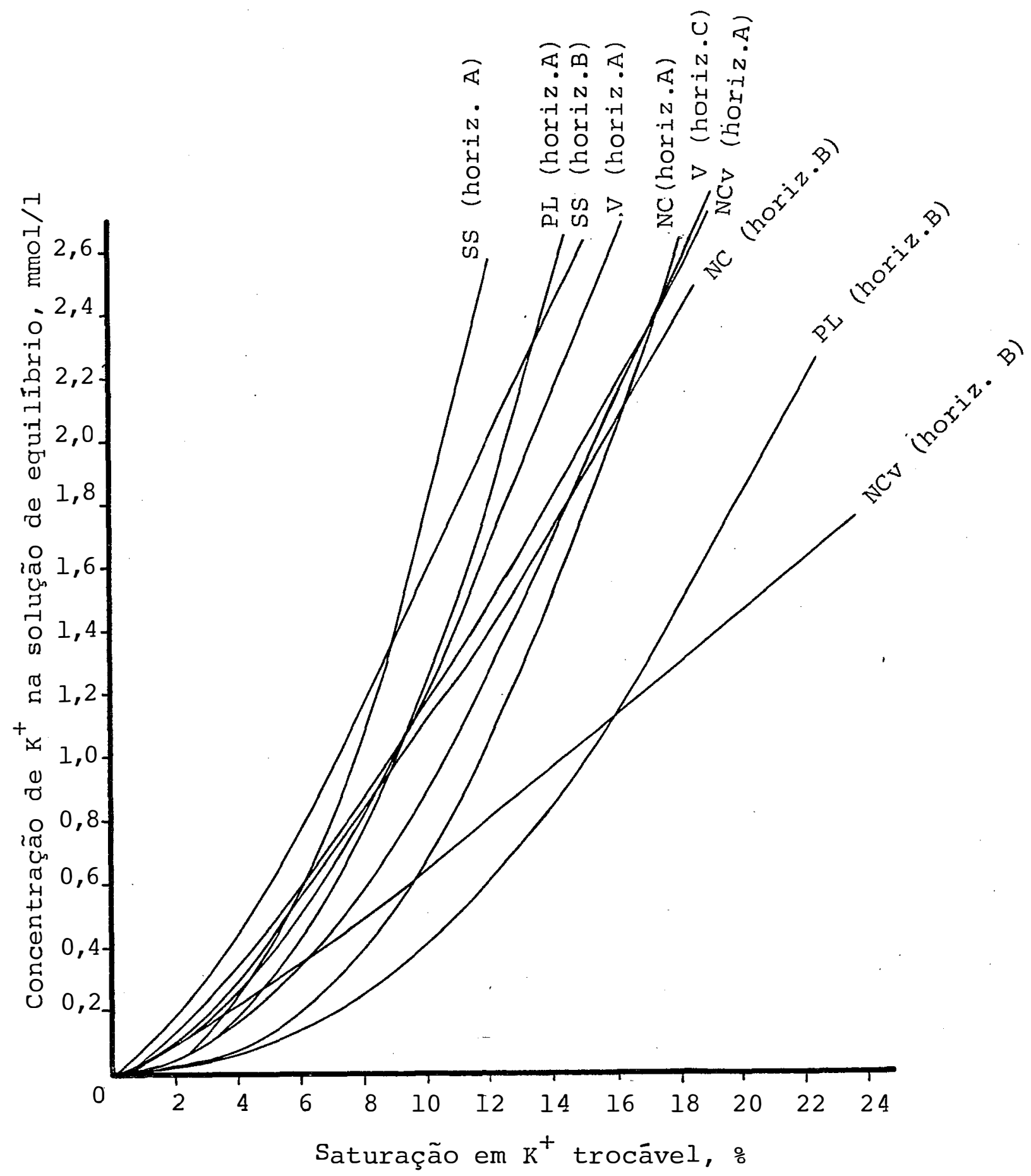

Figura 4 - Variação da concentração do potássio na solução de equilîbrio em função dá porcentagem de saturação em potássio no Vertissol (V), Planossol Solódico (PL), Bruno Não Cál cico (NC), Solonetz Solodizado (SS) e Bruno Não Cálcicovértico (NCv) . 
xa concentração do elemento na solução.Pode-se dizer que isto se deve 'a presença de muita mica e da vermiculita em sua fra ção argila, minerais estes que podem reter fortemente o potássio, liberando-o lentamente para a solução.

As demais amostras de solo: comportam-se de maneira semelhante e podem ser consideradas intermediárias às acima comentadas.

Aplicando-se a equação de Gapon para o V, PL e NC, com intuito de se explicar melhor o comportamento des-. tes em relação à adsorção de potássio, foram obtidas as curvas apresentadas na Figura 5. Elas mostram como a relação $\mathrm{K} /(\mathrm{Ca}+\mathrm{Mg})$ trocáveis (RPT) varia em função da relação entre os mesmos cātions presentes na solução (RAP). As inclinações das curvas representam as constantes de Gapon e estas, a adsorção preferencial de potássio pelos solos.

De maneira geral, a adsorção preferencial de potássio explica a maior ou menor porcentagem de saturação em potássió apresentada por um solo, e varia, conforme esta , com a mineralogia da fração argila dos solos e com o teor de sódio trocável presente nos mesmos. Assim,com base na primeí ra (Tabela 1), poder-se-ia agrupar o $\mathrm{V}$ com O $\mathrm{PL}$, porém, es - 


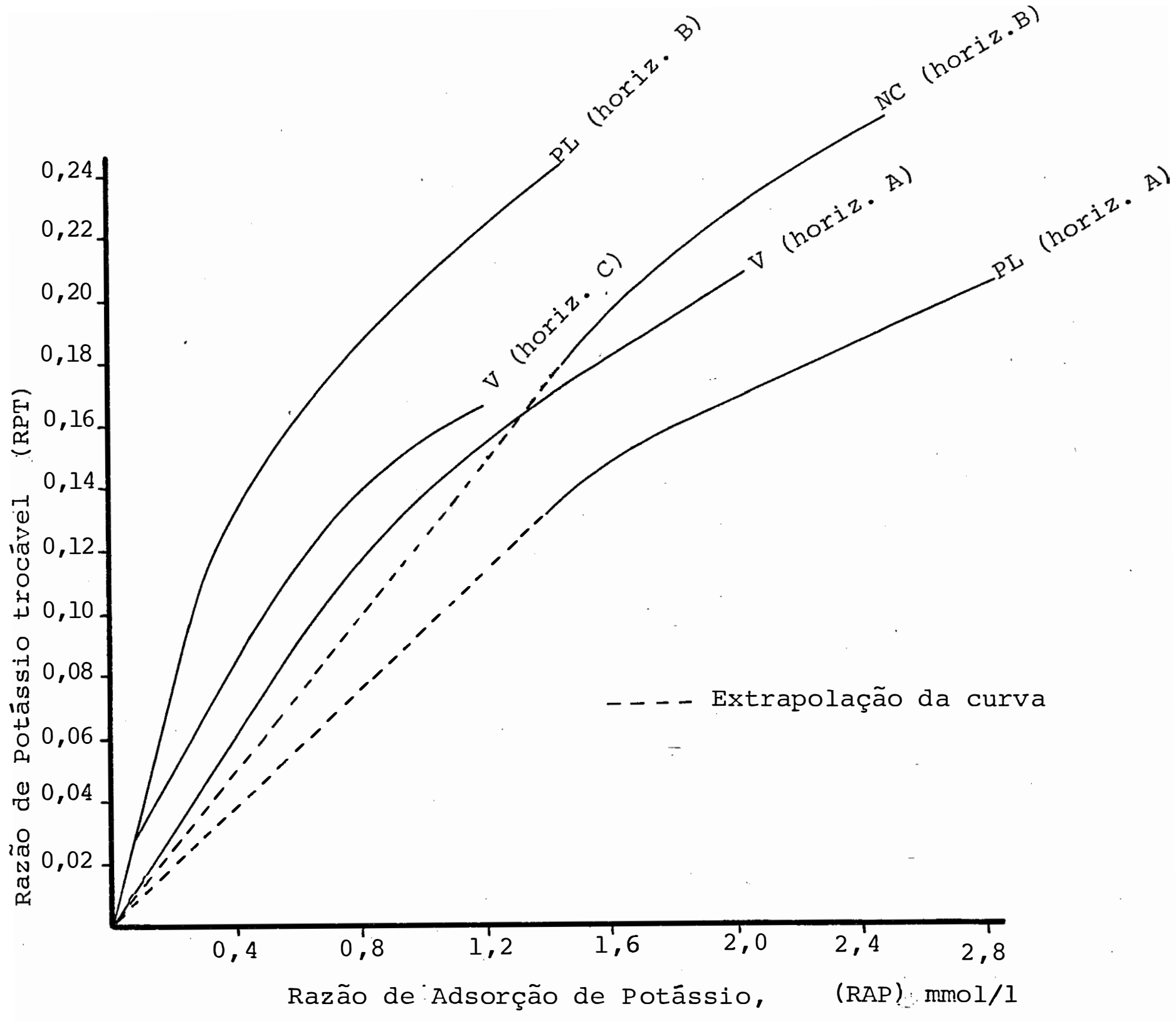

Figura 5 - Adsorção preferencial do potássio para o Vertissol (V), Planossol Solódico (PL) e Bruno Não Cálcjico (NC), obtie da pela Equação de Gapon. 
tes se comportam de maneira diferente quanto à adsorção pre ferencial de potássio devido às suas porcentagens em sódio trocável (Tabela 2), sendo maior a apresentada pelo horizon te $\mathrm{B}$ do $\mathrm{PL}$, seguido do horizonte $\mathrm{A}$ do $\mathrm{PL}$ e dos horizontes $\mathrm{C}$ e A do V:O sōdio, como se sabe, é facilmente deslocado pelo potássio da solução e assim, quanto maior for seu teor no complexo sortivo de um solo, mais facilmente o potássio será adsorvido. No caso do horizonte A do PL, apesar da alta saturação en sódio que apresenta, seu menor teor de argila e, consequentemente, baixa CTC em relação aos horizontes comentados, faz com - o mèsmo adsorva menos potássio que aqueles.

O fato do. horizonte B do NC apresentar maior adsorção preferencial de potássio que o horizonte A do $\mathrm{PL}$, pode ser explicado com base na maior ocorrência de mica e na . presença de vermiculita na fração argila daquele solo, pois estes minerais apresentam forças específicas de retenção de potássio.

4.2. Relação Quantidade/Intensidade de potássio no solo

As relações $Q / I$ de potássio correspondentes a cada solo foram determinadas a partir dos dados apresentados nas Tabelas de 8 a 12, sendo representadas na Figura 6. A partir 
Tabela 8 - Concentração de potássio nas soluções de tratamen to e equilíbrio; concentração de cálcio e magné sio na solução de equilíbrio; variação do potás sio trocável $(\Delta K)$ e quociente de atividade de po tássio (QAK) do Vertissol (horizontes A e C).

$\frac{\mathrm{K}^{+}, \mathrm{mmol} / \mathrm{l}}{\text { tratamento equilíbrio }} \cdots \frac{\Delta \mathrm{K}}{\mathrm{meg} / \mathrm{l} 00 \mathrm{~g}} \frac{\left(\mathrm{Ca}^{2+}+\mathrm{Mg}^{2+}\right)}{\mathrm{mmol} / 1} \frac{\mathrm{QAK}}{(\mathrm{mmol} / \mathrm{l})^{1}} \frac{1 / 2}{n^{2}}$

Horizonte A

$\begin{array}{llrrr}0,000 & 0,025 & -0,250 & 1,80 & 0,02 \\ 0,000 & 0,040 & -0,150 & 1,75 & 0,03 \\ 0,000 & 0,050 & -0,100 & 1,70 & 0,04 \\ 0,000 & 0,062 & -0,062 & 1,80 & 0,05 \\ 0,545 & 0,167 & 0,378 & 1,95 & 0,12 \\ 1,110 & 0,280 & 0,830 & 2,15 & 0,19 \\ 2,160 & 0,525 & 1,635 & 2,50 & 0,33 \\ 2,695 & 0,682 & 2,013 & 2,55 & 0,43 \\ 3,300 & 0,950 & 2,350 & 2,80 & 0,57 \\ 3,780 & 1,065 & 2,715 & 3,05 & 0,61\end{array}$

Horizonte C

$\begin{array}{llrrr}0,000 & 0,014 & -0,140 & 1,75 & 0,01 \\ 0,000 & 0,020 & -0,070 & 1,70 & 0,01 \\ 0,000 & 0,030 & -0,060 & 1,60 & 0,02 \\ 0,000 & 0,027 & -0,027 & 1,65 & 0,02 \\ 0,545 & 0,070 & 0,475 & 1,90 & 0,05 \\ 1,110 & 0,125 & 0,985 & 1,90 & 0,09 \\ 2,160 & 0,301 & 1,859 & 2,35 & 0,20 \\ 2,695 & 0,420 & 2,275 & 2,40 & 0,27 \\ 3,300 & 0,530 & 2,770 & 2,65 & 0,32 \\ 3,780 & 0,772 & 3,008 & 2,95 & 0,45\end{array}$


Tabela 9 - Concentração de potássio nas soluções de tratamen to e equilíbrio; concentração de cálcio e magné sio na solução de equilíbrio; variação de potás sio trocável $(\Delta K)$ e quociente de atividade de po tássio (QAK) do Planossol Solódico (horizontes A e B) •

\begin{tabular}{|c|c|c|c|c|}
\hline \multicolumn{2}{|c|}{$\mathrm{K}^{+}, \mathrm{mmol} / \mathrm{l}$} & \multirow{2}{*}{$\frac{\Delta \mathrm{K}}{\mathrm{meg} / 100 \mathrm{~g}}$} & \multirow{2}{*}{$\frac{\left(\mathrm{Ca}^{2}+\mathrm{Mg}^{2+}\right)}{\mathrm{mmol} / 1}$} & \multirow{2}{*}{$\frac{\operatorname{lak}}{(\pi m \mathrm{l} / 1)^{1 / 2}}$} \\
\hline tratamento & equilíbrio & & & \\
\hline \multicolumn{5}{|c|}{ Horizonte A } \\
\hline $\begin{array}{l}0,000 \\
0,000 \\
0,000 \\
0,000 \\
0,550 \\
0,852 \\
1,072 \\
1,485 \\
2,200 \\
2,730 \\
3,202 \\
3,780 \\
4,042\end{array}$ & $\begin{array}{l}0,035 \\
0,085 \\
0,130 \\
0,197 \\
0,540 \\
0,810 \\
0,930 \\
1,230 \\
1,702 \\
2,172 \\
2,612 \\
2,942 \\
3,255\end{array}$ & $\begin{array}{r}-0,350 \\
-0,319 \\
-0,260 \\
-0,197 \\
0,010 \\
0,042 \\
0,142 \\
0,255 \\
0,498 \\
0,558 \\
0,590 \\
0,838 \\
0,787\end{array}$ & $\begin{array}{r}1,75 \\
1,80 \\
1,80 \\
1,70 \\
1,80 \\
1,80 \\
1,80 \\
1,80 \\
1,90 \\
2,00 \\
2,10 \\
2,20 \\
2,20\end{array}$ & $\begin{array}{l}0,030 \\
0,063 \\
0,097 \\
0,151 \\
0,402 \\
0,603 \\
0,693 \\
0,916 \\
1,235 \\
1,536 \\
1,803 \\
1,984 \\
2,195\end{array}$ \\
\hline
\end{tabular}

Horizonte B

0,000

0,000

0,000

0,000

0,545

1,110

1,513

2,160

2,730

2,940

3,300

3,780
0,012

0,020

0,020

0,027

0,087

0,211

0,307

0,575

0,687

0,770

0,930

1,210
$-0,120$

$-0,070$

$-0,040$

$-0,027$

0,458

0,899

1,206

1,585

2,043

2,170

2,370

2,570
1,65

1,55

1,30

1,15

1,35

1,50

1,50

1,75

2,10

2,00

2,10

2,20
0,01

0,02

0,02

0,02

0,07

0,17

0,25

0,43

0,47

0,54

0,64

0,82 
Tabela 10 - Concentração de potássio nas soluções de tratamen to e equilî̉brio; concentração de cálcio e magné sio na solução de equilíbrio; variação do potás sio trocável $(\Delta K)$ e quociente de atividade de po tássio (QAK) do solo Bruno Não Cálcico (horizon tes $A$ e B).

\begin{tabular}{|c|c|c|c|c|}
\hline \multicolumn{2}{|c|}{$\mathrm{K}^{+}$, mnol/l } & \multirow{2}{*}{$\frac{\Delta \mathrm{K}}{\mathrm{meq} / 100 \mathrm{~g}}$} & \multirow{2}{*}{$\frac{\left(\mathrm{Ca}^{2+}+\mathrm{Mg}^{2+}\right)}{\text { munol/l }}$} & \multirow{2}{*}{$\frac{\mathrm{QAK}}{(\mathrm{m} \mathrm{O} \mathrm{l} / \mathrm{l})^{1 / 2}}$} \\
\hline tratamento & equilíbrio & & & \\
\hline \multicolumn{5}{|c|}{ Horizonte A } \\
\hline $\begin{array}{l}0,000 \\
0,000 \\
0,000 \\
0,000 \\
0,550 \\
0,852 \\
1,072 \\
1,485 \\
2,200 \\
2,730 \\
3,202 \\
3,780 \\
4,042 \\
4,357\end{array}$ & $\begin{array}{l}0,149 \\
0,357 \\
0,607 \\
0,930 \\
1,297 \\
1,554 \\
1,664 \\
1,966 \\
2,434 \\
2,940 \\
3,334 \\
3,701 \\
3,832 \\
4,147\end{array}$ & $\begin{array}{l}-1,490 \\
-1,341 \\
-1,215 \\
-0,930 \\
-0,747 \\
-0,702 \\
-0,592 \\
-0,481 \\
-0,234 \\
-0,210 \\
-0,132 \\
0,079 \\
0,210 \\
0,210\end{array}$ & $\begin{array}{l}1,80 \\
1,60 \\
1,70 \\
1,70 \\
1,70 \\
1,70 \\
1,80 \\
1,80 \\
1,80 \\
2,00 \\
2,00 \\
2,10 \\
2,15 \\
2,10\end{array}$ & $\begin{array}{l}0,11 \\
0,28 \\
0,47 \\
0,71 \\
0,99 \\
1,19 \\
1,24 \\
1,46 \\
1,81 \\
2,08 \\
2,36 \\
2,55 \\
2,61 \\
2,86\end{array}$ \\
\hline \multicolumn{5}{|c|}{ Horizonte B } \\
\hline $\begin{array}{l}0,000 \\
0,000 \\
0,000 \\
0,000 \\
0,545 \\
1,018 \\
1,110 \\
1,513 \\
2,160 \\
3,300 \\
3,780\end{array}$ & $\begin{array}{l}0,009 \\
0,020 \\
0,030 \\
0,030 \\
0,312 \\
0,-510 \\
0,660 \\
0,915 \\
1,350 \\
2,310 \\
2,585\end{array}$ & $\begin{array}{r}-0,090 \\
-0,070 \\
-0,060 \\
-0,030 \\
0,233 \\
0,508 \\
0,450 \\
0,598 \\
0,810 \\
0,990 \\
1,195\end{array}$ & $\begin{array}{l}1,70 \\
1,75 \\
1,70 \\
1,65 \\
1,90 \\
1,80 \\
1,95 \\
1,95 \\
2,10 \\
2,20 \\
2,30\end{array}$ & $\begin{array}{l}0,01 \\
0,01 \\
0,02 \\
0,02 \\
0,23 \\
0,38 \\
0,47 \\
0,65 \\
0,93 \\
1,56 \\
1,70\end{array}$ \\
\hline
\end{tabular}


Tabela 11 - Concentração de potássio nas soluções de tratamen to e equilíbrio; concentração de cálcio e magné sio na solução de equilíbrio; variação do potássio trocável $(\Delta K)$ e quociente de atividade de po tássio (QAK) do Solonetz Solodizado (horizontes A e B) .

$\frac{\mathrm{K}^{+}, \mathrm{mmol} / \mathrm{l}}{\text { tratamento equilíbrio }} \frac{\Delta \mathrm{K}}{\mathrm{meg} / \mathrm{l} 00 \mathrm{~g}} \frac{\left(\mathrm{Ca}^{2+}+\mathrm{Mg}^{2+}\right)}{\mathrm{mmol} / \mathrm{l}} \frac{\mathrm{QAiK}:}{(\mathrm{mmol} / \mathrm{l})^{1 / 2}}$

$\underline{\text { Horizonte } \mathrm{A}}$

0,000

0,000

0,000

0,000

0,545

1,110

2,160

2,695

3,300

3,780

0,000

0,000

0,000

0,000

0,545

1,110

1,513

2,160

3,300

3,780
0,040

0,090

0,150

0,227

0,617

1,035

1,919

2,370

3,000

3,327

0,020

0,040

0,040

0,082

0,261

0,466

0,734

1,057

1,740

2,117
$-0,400$

$-0,340$

$-0,300$

$-0,227$

$-0,072$

0,075

0,241

0,325

0,300

0,453

Horizonte B

$-0,200$

$-0,150$

$-0,080$

$-0,082$

0,284

0,644

0,779

1,103

1,560

1,663
1,70

1,70

1,75

1,65

1,80

1,80

1,85

1,95

1,90

1,85

0,03

0,07

0,11

0,18

0,46

0,77

1,41

1,70

2,18

2,45

1,65

1,65

1,55

1,50

1,55

1,70

1,85

2,00

0,02

0,03

0,03

0,07

0,21

0,36

$0,5 \overline{4}$

0,75

2,10

1,20

2,20

1,43 
Tabela 12 - Concentração de potássio nas soluções de tratamen to e equilíbrio; concentração de cálcio e magné sio na solução de equilíbrio; variação do potássio trocável $(\Delta K)$ e quociente de atividade de potássio pelo solo-Bruno Não Cálcico vértico (horizontes $A$ e B).

\begin{tabular}{|c|c|c|c|c|}
\hline \multicolumn{2}{|c|}{$\mathrm{K}^{+}, \mathrm{mmol} / \mathrm{l}$} & \multirow{2}{*}{$\frac{\Delta \mathrm{K}}{\mathrm{meg} / 100 \mathrm{~g}}$} & $\left(\mathrm{Ca}^{2+}+\mathrm{Mg}^{2+}\right)$ & \multirow{2}{*}{$\frac{\mathrm{QAK}}{(\mathrm{m} \mathrm{mol} / 1)^{1 / 2}}$} \\
\hline tratamento & equilíbrio & & ஈயா101/1 & \\
\hline \multicolumn{5}{|c|}{ Horizonte A } \\
\hline $\begin{array}{l}0,000 \\
0,000 \\
0,000 \\
0,000 \\
0,545 \\
0,852 \\
1,072- \\
1,513 \\
2,160 \\
2,695 \\
3,300 \\
3,780\end{array}$ & $\begin{array}{l}0,022 \\
0,040 \\
0,060 \\
0,082 \\
0,369 \\
0,577 \\
0,756 \\
1,095 \\
1,425 \\
1,950 \\
2,450 \\
2,915\end{array}$ & $\begin{array}{l}-0,220 \\
-0,150 \\
-0,120 \\
-0,082 \\
0,176 \\
0,275 \\
0,316 \\
0,418 \\
0,735 \\
0,745 \\
0,850 \\
0,865\end{array}$ & $\begin{array}{l}1,75 \\
1,70 \\
1,70 \\
1,75 \\
1,80 \\
2,00 \\
1,80 \\
1,85 \\
2,05 \\
2,10 \\
2,15 \\
2,10\end{array}$ & $\begin{array}{l}0,02 \\
0,03 \\
0,05 \\
0,06 \\
0,27 \\
0,41 \\
0,56 \\
0,80 \\
0,99 \\
1,35 \\
1,67 \\
2,01\end{array}$ \\
\hline \multicolumn{5}{|c|}{ Horizonte B } \\
\hline $\begin{array}{l}0,000 \\
0,000 \\
0,000 \\
0,000 \\
0,545 \\
1,018 \\
1,110 \\
1,513 \\
2,160 \\
2,695 \\
3,300 \\
3,780\end{array}$ & $\begin{array}{l}0,015 \\
0,010 \\
0,020 \\
0,026 \\
0,230 \\
0,360 \\
0,400 \\
0,502 \\
0,790 \\
0,975 \\
1,420 \\
1,430\end{array}$ & $\begin{array}{r}-0,150 \\
-0,040 \\
-0,040 \\
-0,026 \\
0,315 \\
0,658 \\
0,710 \\
1,011 \\
1,370 \\
1,720 \\
1,880 \\
2,350\end{array}$ & $\begin{array}{l}1,70 \\
1,90 \\
1,75 \\
1,75 \\
1,85 \\
1,85 \\
1,95 \\
2,00 \\
2,40 \\
2,45 \\
2,55 \\
2,60\end{array}$ & $\begin{array}{l}0,01 \\
0,01 \\
0,01 \\
0,02 \\
0,17 \\
0,26 \\
0,29 \\
0,35 \\
0,51 \\
0,62 \\
0,89 \\
0,89\end{array}$ \\
\hline
\end{tabular}




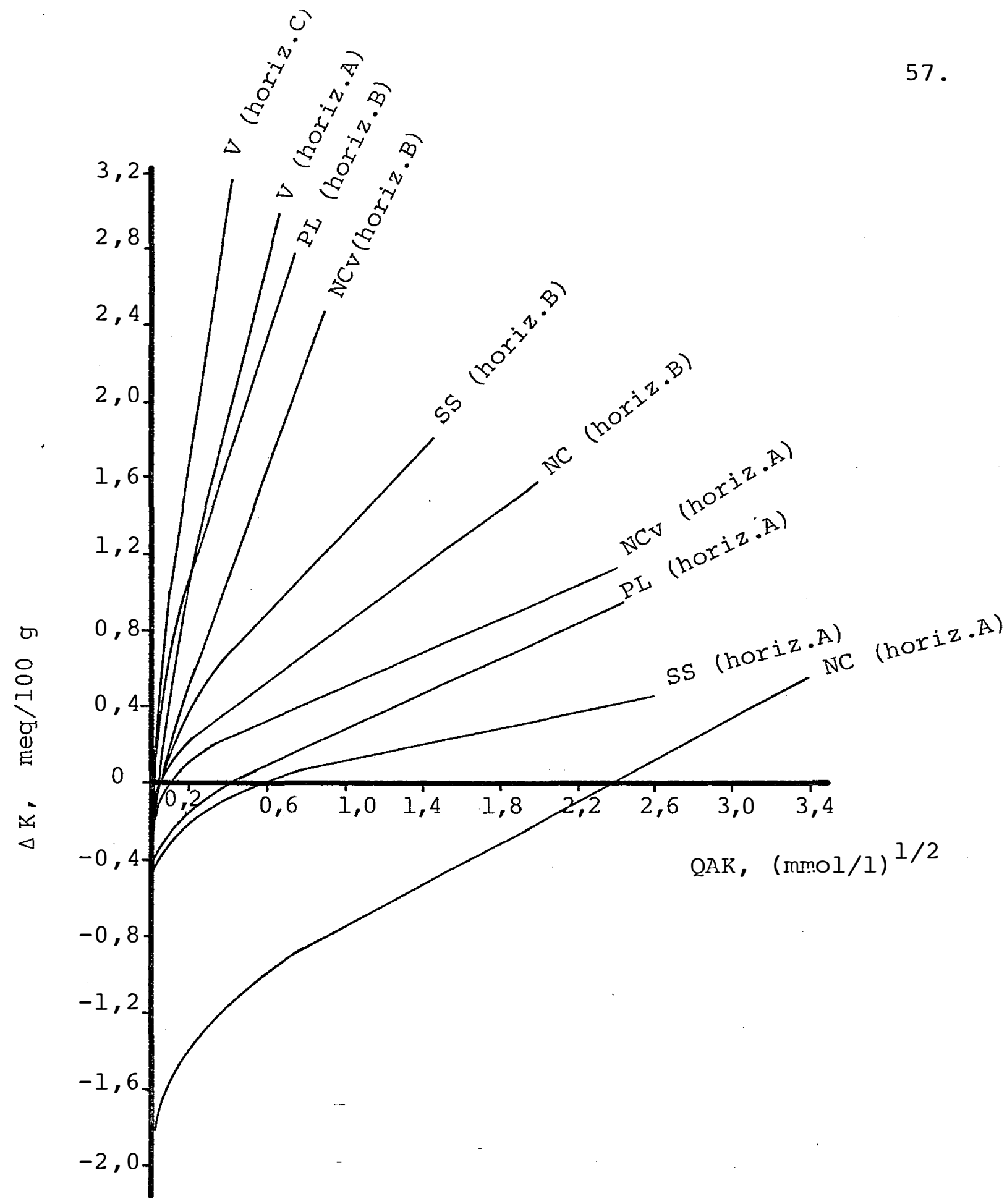

Figura 6 - Curvas representativas da relação Q/I do Vertissol (V), Planossol Solódico (PL), Bruno Não Cálcico (NC), Solonetz Solodizado (SS) e Bruno Não Cálcico-vértico (NCv). 
delas foram estimados os valores de potássio sujeito a equilíbrio com a solução, suas subdivisões em potássio planar e preferencial, e as posições preferenciais não ocupadas pelo potássio; esses dados são mostrados na Tabela 13 .

Observa-se que somente as amostras do horizon te $\mathrm{A}$ do $\mathrm{PL}, \mathrm{NC}$ e SS e, as do horizonte $\mathrm{B}$ do $\mathrm{NCv}$, apresentam potássio na posição planar, o que permite, de maneira geral , que mantinham maiores níveis do elemento na solução do solo, como se verá adiante.

As amostras do horizonte $\mathrm{A}$ do $\mathrm{V}$ e $\mathrm{NCV}$, do horizonte $\mathrm{B}$ do $\mathrm{PL}, \mathrm{NC}$ e SS e horizonte C do $\mathrm{V}$, têm todo seu potássio sujeito a equilíbrio, adsorvido nas posições preferenciais, sendo estas não totalmente saturadias. As posições preferenciais não ocupadas pelo potássio no momento da análise, representam a quantidade do elemento que falta ao solo para que este possa apresentar, a partir dái, potássio na posição planar.

O conhecimento do teor do elemento que está adsorvido em uma ou outra posição é de extrema importância , principalmente quando se compara solos em relação à disponibilidade do elemento para as plantas, baseando-se apenas nos 
Tabela 13 - Potássio sujeito a equilíbrio com a solução; potássio planar e preferencial e posições preferen ciais não ocupadas por potássio, obtidos a partir das curvas Q/I de potássio.

\begin{tabular}{clccc}
\hline \multirow{2}{*}{ Horizonte } & $\begin{array}{l}\mathrm{K}^{+} \text {sujeito a } \\
\text { equilíbrio can } \\
\text { a solução }\end{array}$ & $\mathrm{k}$-planar & $\begin{array}{l}\mathrm{k} \text {-preferen } \\
\text { cial atual }\end{array}$ & $\begin{array}{l}\text { Posições prefe } \\
\text { renciais não } \\
\text { ocupadas cam } \mathrm{K}\end{array}$ \\
\hline
\end{tabular}

Vertissol
A'
0,36
$\because$.
0,36
0,39
C
0,23
0,23
0,40

$\underline{\text { Planossol Solódico }}$
A
0,42
0,19
0,23
0,00
B
0,13
0,13
0,42

Bruno Não Cálcico
A
1,85
1,30
0,55
0,00
B
0,16
0,16
0,06

Solonetz Solodizado
A
0,48
0,13
0,35
0,00
B
0,36
0,36
0,25

Bruno Não Cálcico-vértico
A
0,26
..
0,26
0,04
B
0,14
0,07
0,07
0,00 
teores de potássio trocável. É comum a afirmativa de que quanto maior o teor deste nos solos, mais potássio é mantido em solução, o que nem sempre é verdadeiro. Comparando-se o horizonte $\mathrm{C}$ do $\mathrm{V}$ com o horizonte $\mathrm{B}$ do $\mathrm{NCv}$, quanto aos seus teores de potássio sujeito à equilíbrio com a solução, obser va-sé que o primeiro apresenta teor mais elevado que o segun do, mantendo, porém, mẹnor nível de potássio na solução de equilíbrio (Tabela 14). Uma das razões para isto é que o ele mento naquele solo encontra-se totalmente retido nas posições preferenciais, enquanto que no solo NCv, uma parte do potássio está retida na posição planar, sendo mais facilmente liberado para a solução.

A porcentagem de saturação em potássio e os parâmetros Q/I obtidos a partir das curvas apresentadas na Figura 6, são apresentados na Tabela 14. Observa-se uma ampla variação dos dados, o que já era esperado, visto que os solos em estudo se diferenciam tanto pelas características químicas como físicas.

Os valores de QAKe, que é uma relação de atividades do potássio e cálcio mais magnésio presentes na solu ção de equilíbrio, variam de 0,010 (mmol/l1 ${ }^{1 / 2}$ no horizonte $\mathrm{C}$ do $\mathrm{V}$ a 2,405 (mol/l $)^{1 / 2}$ no horizonte $A$ do NC. Os seus cor respondentes valores de Ke, que constitui o teor de potássio 
Tabela 14 - Saturação em potássio e parâmetros Q/I.

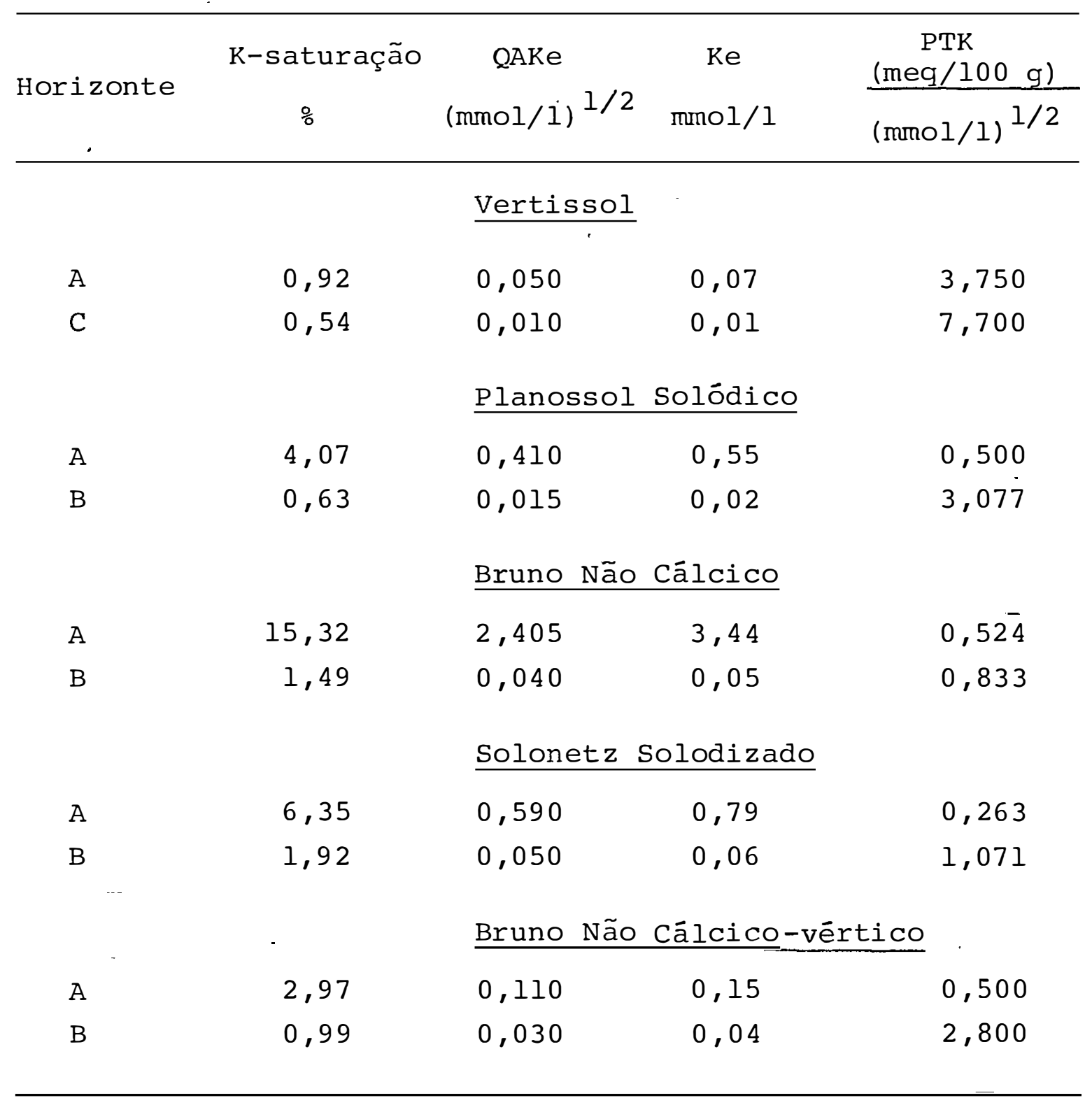


na solução no momento do equilíbrio, são 0,01 e 3,52 mol/1, respectivamente. De acordo com critérios estabelecidos por Mengel et alii. (1973) e Grimme (1976), citados por MIELNIC ZUK ( 1980), apenas os horizontes A do PL, NC, SS e NCV, apre sentam adequados valores de tais parâmetros para um bom desenvólvimento vegetal. Isto comprova a importância do conhecimento da relação Q/I dos solos, pois, com base apenas nos valores de potássio trocável (Tabela 2), determinados pelo método tradicional, poder-se-ia dizer que nenhum solo apre senta problema à respeito de potássio, já que possuem teores deste variando de médio a alto.

O horizonte C do $\mathrm{V}$ e O.B do PL apresentam os menores valores de QAKe è Ke, o que pode estar relacionado às baixas porcentagens de saturação em potássio dos solos e ao fato de possuirem baixos valores correspondentes à rela ção $\mathrm{K}^{+}$trocável/(Ca $\left.{ }^{2+}+\mathrm{Mg}^{2+}\right)$ trocáveis (BECKETT, 1964b) . o horizonte A do NC constitui o caso oposto, isto é, apresenta os maiores valores para os parâmetros mencionados. As variações do QAKe e Ke em função da porcentagem de saturação em potássio e da relação $\mathrm{K}^{+} \operatorname{trocável} /\left(\mathrm{Ca}^{2+}+\mathrm{Mg}^{2+}\right)$ trocáveis,po dem ser comprovadas pelos altos coeficientes de correlação apresentados na Tabela 15. 
Tabela 15 - Relação entre parâmetros Q/I e algumas propriedạ des do solo.

\begin{tabular}{|c|c|c|c|c|}
\hline \multicolumn{2}{|r|}{ Variáveis } & \multirow{2}{*}{$\begin{array}{c}\text { Coeficiente } \\
\text { de correlação }\end{array}$} & \multirow{2}{*}{ Equação de } & \multirow{2}{*}{ Regressão } \\
\hline$\dot{y}$ & $\mathrm{x}$ & & & \\
\hline QAKe & $\begin{array}{l}\text { \% } \mathrm{k} \text {-saturação } \\
\mathrm{K}^{+} \text {trocável }\end{array}$ & $r=0,98 * *$ & $y=-0,196$ & $+0,161 \mathrm{x}$ \\
\hline QAKe & $\begin{array}{l}\left(\mathrm{Ca}^{2+}+\mathrm{Mg}^{2+}\right) \text { trocá } \\
\text { veis }\end{array}$ & $r=0,96 * *$ & $y=-0,165$ & $+10,874 x$ \\
\hline $\mathrm{Ke}$ & $\begin{array}{l}\text { : K-saturação } \\
\mathrm{K}^{+} \text {trocável }\end{array}$ & $r=0,98 * *$ & $y=-0,290$ & $+0,230 x$ \\
\hline $\mathrm{Ke}$ & $\begin{array}{l}\left(\mathrm{Ca}^{2+}+\mathrm{Mg}^{2+}\right) \text { trocá } \\
\text { veis }\end{array}$ & $r=0,95 * *$ & $y=-0,245$ & $+15,481 x$ \\
\hline PTK & СТС $\mathrm{pH} 7$ & $r=0,90 * *$ & $y=-1,006$ & $+0,169 x$ \\
\hline PTK & \% argila & $r=0,83 * *$ & $y=-1,338$ & $+0,133 \mathrm{x}$ \\
\hline
\end{tabular}

O conhecimento do PTK de um solo é importante no que diz respeito à reposição do potássio em sua solução e consequentemente, ao suprimento de potássio às plantas. 
Segundo MIELNICZUK (1980), quando se compara dois solos com mesmos teores de K-trocável e K-solução, sen do estes considerados baixos e aqueles altos, o solo que apresentar PTK mais elevado, suprirá mais potássio às plantas que aquele com PTK mais baixo. Assim, comparando-se o horizonte A do $\mathrm{V}$ e ó B do SS, pode-se dizer que, culturas instaladas no primeiro, provạvelmente, serão mais bem suprí das de potássio que as cultivadas no segundo.

Pelos dados da Tabela 14 nota-se uma tendên cia para que os solos com QAKe, e consequentemente Ke, mais elevados, possuam PTK relativamente baixos, concordando com observações feitas por GAMA (1966).

De acordo com o exposto no ítem anterior,atra vēs da relação Q/I, os valores de PTK mais elevados foram correspondentes aos horizontes A e C do V e o menor ao hori zonte A do SS, havendo conforme Beckett (1958) citado por MATHEWS e BECKETT (1962) e GOEDERT et alii. (1975), uma rela ção altamente significativa entre PTK e CTC à pH 7,0 dos solos (Tabela 15).

O tipo de argila predominante e sua porcenta gem de ocorrência nos solos influenciam, de maneira conjunta e indireta, o PTK dos mesmos. 
Comparando-se o horizonte B do PL e SS, nota-se que eles possuem semelhantes porcentagens de argila $(33,7$ e 37,8 \% respectivamente), porém, diferentes valores de PTK, 3,077 e 1,071 (meq/100 g)/(mol/l) $1 / 2$, respectivamen te. A explicação para isto está na diferença entre os tipos de árgila que predominam em cada solo. No primeiro ocorre de 20 a 50 \% de mica e montmorilonita, e no segundo, acima de 50 \% de caulinita, mostrando que os minerais com maior СТC possibilitam maior valor de PTK para os solos.

O horizonte $\mathrm{C}$ do $\mathrm{V}$, que possui acima de $50 \%$ de montmorilonita na sua fração argila, apresenta o maior valor de PTK c̈entre os estudados, sendo um dos motivos para tal, a alta capacidade de troca catiônica do mineral (80$120 \mathrm{meq} / 100 \mathrm{~g}$ ) (Scheffer e Schachtschabel, 1966 citados por FASSBENDER, 1980). O contrário deveria acontecer no horizonte $B$ do SS, que possui em sua fração argila mais de 50 \% de caulinita. Esta apresenta baixa capacidade de troca catiôni-... ca (3-15 meq/100 g), porém, neste caso, o horizonte não apre senta o menor valor de PTK porque seu teor de argila é eleva do (37,8 \%), contribuindo para o não abaixamento do parâme tro em questão.

Outro caso da influência do teor de argila no PTK é constituido pelos horizontes A e B do NCv. Ambos pos- 
suem os mesmos tipos de argila mesmas proporções, porem, com diferentes teores $(11,8$ e $22,8 \%)$, possibilitando ao ho rizonte A um PTK correspondente a 0,50 enquanto que ao B, $2,80(\mathrm{meq} / 100 \mathrm{~g}) /(\mathrm{mmol} / \mathrm{l})^{1 / 2}$

De acordo com o que foi citado e apresentado na Tabela 15, a porcentagem de argila correlaciona-se de maneira significativa com O PTK, contrariamente ao observado por GOEDERT et alii (1975) para os solos do Rio Grande do Sul. Os autores justificam a falta de correlação devido 'a heterogeneidade de mineralogia entre os solos analisados.

Devido à complexidade do assunto em questão e à sua importância, no que diz respeito à disponibilidade de potássio para as plantas, recomenda-se um estudo mais profundo sobre a dinâmica do potássio em cada solo. 
5. CONCLUSÕES

De acordo com os resultados obtidos foram pos síveis as seguintes conclusões:

\subsection{Adsorção de potássio}

A quantidade de potássio adsorvido nos solos, nas condições do experimento, aumenta com a elevação de sua concentração nas soluções de tratamento. Os solos que adsorvem mais potássio são os que apresentam valores mais eleva dos de CTC, ou por causa do maior teor de argila que possuem, ou devido à composição mineralógica desta fração.

A concentração de potássio nas soluções de equilíbrio dos solos está relacionada, em função potencial, com a quantidade total de potássio trocável presente nos res 
pectivos solos. Assim, o maior valor de PTK é apresentado pelo Vertissol e o menor pelo Solonetz Solodizado. Para se analisar os solos em conjunto, pode-se dizer que o parâme tro que melhor se relaciona com a concentração de potássio na solução é a porcentagem de saturação em potássio.

O sódio do complexo sortivo dos solos influen cia, de maneira direta e proporcional, na adsorção preferen cial de potássio pelos mesmos.

5.2. Relação Quantidade/Intensidade de potássio no solo

A concentração de potássio na solução " de equilíbrio depende da posição em que o elemento se encontra adsorvido no solo. Assim, os solos que apresentam potássio trocável adsorvido na posição planar são os que mantém maio res concentrações do elemento na solução, ocorrendo o inverso com aqueles que apresentam maior quantidade do elemento nas posições preferenciais. Entṛe os solos analisados, - Bruno Não Cálcico apresenta a maior quantidade de potássio - na posição planar e,consequentemente,maior concentração de potássio na solução de equilíbrio.

Os parâmetros quociente de atividade de potássio em equilíbrio (QAKe) e potássio em equilíbrio (Ke) , 
correlacionam-se de maneira significativa com as porcentagens de saturação em potássio e relação $\mathrm{K}^{+}$trocável/Ca ${ }^{2+}+\mathrm{Mg}^{2+}$ ) trocáveis.

O quociente $\triangle \mathrm{K} / \mathrm{QAK}$, chamado de poder tampão do solo (PTK), é diretamente proporcional à CTC dos solos, es tando, portanto, relacionado à porcentagem de argila presente nestes e à sua composição mineralógica.

Os horizontes A de todos os solos, com exceção do Vertissol, apresentam os menores valores de PTK e mantem altos níveis de Ke. 
70.

6. LITERATURA CITADA

ACQUAYE, D.K.; A.J. MACLEAN e H.M. RICE, 1967. Potencial and capacity of potassium in some representative soils of Ghana. Soil Sci. Baltimore, 103(2): 79-89.

AHMAD, N. e R.L. JONES, 1969. Genesis, chemical properties and mineralogy of Caribean Grumosols. Soil Sci. Baltimo re, 107: 166-74.

ATTOE, O.J. e E. TRUOG, 1945. Exchangeable and acid solu ble potassium as regards availability and reciprocal rela tionships. Soil Sci. Soc. Amer. Proc. Madison, 10: 81 6 . 
BECKETT, P.H.T., 1964a. Studies on soil potassium. I. Confirmation of the ratio law: measurement of potassium potential. J. Soil Sci. Oxford, 15: 1-18.

BECKETT, P.H.T., 1964b. Studies on soil potassium. II. The "immediate" Q/I relations of labile potassium in the soil. J. Soil Sci. Oxford, 15: 9-23.

BECKETT, P.H.T. e M.H.M. NAFADY, 1967. Studies on soil potassium. VI. The effect of $\mathrm{K}$-fixation and release on the form of the $\mathrm{K}:(\mathrm{Ca}+\mathrm{Mg})$ exchange ișotherm. J. Soill Sci. Oxford, 18: 244-62.

BOLARIN, M.C.; M. CARO; F.G. FERNANDEZ e M. ROMERO, 1980. Influência del tempo de equilibrio sobre las relaciones Q/I de potasio en suelos y arcillas. Anales de Edafologia y Agrobiologia, Madrid, $39(1 / 2):$ 187-201.

BOLT, G.W.;-M.E. SUMNER e A. KAMPHORST, 1963. A study of three categories of potassium in am illitic soil. Soil Sci. Soc. Amer. Proc. Madison, 27: 294-99.

BOUYOUCOS, G.J., 1951. A recalibration of the hydrometer methods for making analysis of soils. Agron. J. Madison, 43: $434-38$. 
BRASIL. Ministério da Agricultura. Divisão de Agrologia, 1972. I. Levantamento Exploratório - Reconhecimento de Solos do Estado da Paraíba. II. Interpretação para uso agrícola dos solos do Estado da Paraíba. Rio de Janeiro, 693 p. (Boletim Técnico no '15).

CAMARGO, M.N. e J. BENNEMA, 1966. Delineamento esquemático dos solos do Brasil. Pesg. agropec. bras. Rio de Janeiro, 1: $47-54$.

CASTRO, A.F.; M.L.A. ANASTÁCIO e W.O. BARRETO, 1972. Potássio disponivel em horizontes superficiais de alguns solos brasileiros. Pesq. agropec. bras., Série Agron. Rio de Janeiro, $\underline{7}: 75-80$.

CATANI, R.A. e A.O. JACINTHO,1974. Avaliação da fertilidade do solo; métodos de análise. Piracicaba, Livroceres, 61 p.

CRISÓSTOMO, L.A. e A.F. de CASTRO, 1970. Poder de suprimento de potássio de solos da zona fisiogrà́fica de Baturité, Cea rá, Brasil. Turrialba, Turrialba, $20(4):$ 425-33.

DIAS, A.C.C.P., 1971. Mineralogia da fração argila de alguns solos da Bacia Sedimentar do Recôncavo Baiano. Piracicaba, ESALQ/USP, 98 p. (Dissertação de Mestrado). 
FASSBENDER, H.W., 1980. Química de Suelos. Turrialba, Instituto Interamericano de Ciências Agrícolas 398 p.

FERREIRA, N.C.M., 1978. Seletividade catiônica e propriedades eletroquímicas de algunś solos do Estado de Pernambuco. Piracicaba, ESALQ/USP, 96 p. (T'ese de Doutoramento).

GAMA, M.V. da, 1966. Potencial e capacidade dalguns solos em relação ao potássio e sua variação em o cultivo. Agronomia Lusitana. Oeiras, 28: 105-23.

GOEDERT, W.J.; J.L. SYERS e R.B. COREY, 1975. Relações quạn tidade-intensidade de potássio em solos do Rio Grande do sull. Pesq. agropec. bras., Série Agron. Rio de Janeiro, $10: 31-5$.

GRAHAM, E.R. e R.L. FOX, 1971. Tropical soil potassium as related to lebile pool and calcium exchange equilibria. Soil Sci. Baltimore, lll $(5): 318-22$.

HAROWITZ, A. e A. MAKITIE, 1963. Observações sobre algumas argilas dos solos do Nordeste. B. Tec. Inst. Pesq. e Exper. Agropec. Nord. Recife, 21: 1-33. 
JACKSON, M.L., 1973. Soil chemical analysis, advanced course. 2 ed. Madison, 991 p.

JARVIS, N.L.; R. ELLIS Jr. e O.W. BIDWELL, 1959. A chemical and mineralogical characterization of selected Brunizem, Reddish prairie, Grumusol and Planosol soils developed in pleistocene materials. Soil Sci. Soc. Amer. Proc. Madison, 23: 234-9.

JOHNSON, W.M.; J.G. CADY e M.S. JAMES, 1962. Characteris tics of some brown Grumosols of Arizona. Soil Sci. Soc. Am. Proc. Madison, 26: 389-93.

KHASAWNEH, F.E., 1971. Solution ion activity and plant growth. Soil Sci. Soc. Am. Proc. Madison, 35: 426-36.

KOCH, J.T.; E.R. ORCHARD e M.E, SUMNER, 1970. Leaf composition and yield response of corn in relation to quantityintensity parameters for potassium. Soil Sci. Soc. Am. Proc. Madison, 34: 94-8.

LEITE, J.P.; H.S. DANTAS e M. MONTENEgRO FILHO, 1973. Avaliação química dos solos do Agreste de Pernambuco. B.Tec. Inst. de Pesg. Agron. Recife, no 60. 32 p. 
LOPES, A.S., 1982. Mineralogia do potássio em solos do Brasil. In: YAMADA, T. (ed.), Potássio na Agricultura Brasileira. Piracicaba, Instituto Internacional da Potassa. p. 51-65.

MARANHÃO, R.J.L.; M.F.L. FALCÃO; J.P.LEITE e H.S. DANTAS, 1974. Análise mineralógica das frações calhau e cascalho em solos do Agreste de Pernambuco. B. Tec. Inst. de Pesg. Agron. Recife, no 70. 30 p.

MIELNICZUK, J., 1977. Formas de potássio em solos do Bra sil. R. bras.Ci. Solo, Campinas, le: 55-61.

MIELNICZUK, J., 1980. O potássio no solo. Piracicaba, Ins tituto Internacional da Potassa. 80 p. (Boletim Técnico,2).

MIRANDA, E.R. e K. IGUE, 1972. Quantidade/Intensidade de po tássio em solos da região cacaueira da Bahia. Theobroma. Itabuna, 2 $(3): 47-55$.

MOJICA, F.S.; L.I.O. RODRIGUEZ e B.M. MUÑOZ, 1973. Métodos Analíticos del Laboratorio de Suelos. Bogotá, Instituto Geográfico "Agustin Codazzi". 172 p. 
MOREIRA, E.G.S., 1979. Caracterização e gênese de três pe dons de Solonetz Solodizado do Sertão Central e do Médio Jaguaribe - Estado do Ceará. Piracicaba, ESALQ/USP, 83 p. (Tese de Doutoramento).

NELSON, L.A.; G.W. KUNZE e C.L. GODOFREY, 1960. Chemical and mineralogical properties of San Saba Clay, a Grumosol. Soil Sci. Baltimore, 89: 122-31.

OLIVEIRA, J.J., 1981. Micromorfologia, mineralogia e ultramicroscopia da fase de alteração de rochas graníticas em dominio bioclimático semi-árido da Bahia. In: XVIII Congresso brasileiro de ciência do solo. Salvador. Progra mas e Resumos. p. 31.

QUEMENER, J., 1979. The measurement of soil potassium. Bern, International Potash Institute: 48 p. (IPI Research Topics, no 4).

RAIJ, B. van, 1981. Avaliação da fertilidade do solo. Pira cicaba, Instituto Internacional da Potassa, $142 \mathrm{p}$.

RITCHEY, K.D., 1979. Potassium fertility in Oxisols and Ulti-. sols of the umid tropics. Cornell International Agriculture Bulletin $37.45 \mathrm{p}$. 
SCHUFFELEN, A.C., 1972. The cation exchange system of the soil. In: Potassium in soil. Federal Republic of Germany, International Potash Institute. p. 75-88. (Proceedings of the 9 th Colloquium).

TALIBUDEEN, O., 1972. Exchange of potassium in soils in re lation to other, cations. In: Potassium in soil. Federal Republic of Germany, International Potash Institute. p.97112. (Proceedings of the 9th Colloquium).

WHITTIG, L.D., 1965. X-ray diffraction techniques for mineral identification and mineralogical composition. In: BLACK, C. A. (ed.), Methods of soil analysis. Madison, Am. Soc. Agron. vl. p. 671-98 (Agronomy, 9). 